University of Chicago Law School

Chicago Unbound

\title{
The Boundaries of Vicarious Liability: An Economic Analysis of the Scope of Employment Rule and Related Legal Doctrines
}

Alan O. Sykes

Follow this and additional works at: https://chicagounbound.uchicago.edu/journal_articles

Part of the Law Commons

\section{Recommended Citation}

Alan O. Sykes, "The Boundaries of Vicarious Liability: An Economic Analysis of the Scope of Employment Rule and Related Legal Doctrines," 101 Harvard Law Review 563 (1987).

This Article is brought to you for free and open access by the Faculty Scholarship at Chicago Unbound. It has been accepted for inclusion in Journal Articles by an authorized administrator of Chicago Unbound. For more information, please contact unbound@law.uchicago.edu. 


\title{
HARVARD LAW REVIEW
}

\section{ARTICLES}

\section{THE BOUNDARIES OF VICARIOUS LIABILITY: AN ECONOMIC ANALYSIS OF THE SCOPE OF EMPLOYMENT RULE AND RELATED LEGAL DOCTRINES}

\author{
Alan O. Sykes
}

66 JICARIOUS liability" may be defined as the imposition of liability upon one party for a wrong committed by another party. ${ }^{1}$ One of its most common forms is the imposition of liability on an employer for the wrong of an employee or agent.

The imposition of vicarious liability usually depends in part upon the nature of the activity in which the wrong arises. For example, if an employee (or "servant") commits a tort within the ordinary course of business, the employer (or "master") normally incurs vicarious liability under principles of respondeat superior. If the tort arises outside the "scope of employment," however, the employer does not incur liability, absent special circumstances. ${ }^{2}$ Roughly speaking, this "scope of employment rule" restricts vicarious liability to tortious conduct that "should be considered as one of the normal risks to be borne by the business,"3 thereby excluding an employee's "personal" torts.

\footnotetext{
* Assistant Professor of Law, University of Chicago Law School. I have received helpful comments on prior drafts of this Article from Albert Alschuler, Richard Epstein, David Haddock, Fred McChesney, Richard Posner, Stephen Schulhofer, and Steven Shavell, and from the participants in the Law and Economics Workshop of the University of Chicago. I also wish to thank the Lynde and Harry Bradley Foundation, which provided financial support for this research.

1 Vicarious liability has received increasing academic attention in recent years, much of it from the economic perspective. See, e.g., Kornhauser, An Economic Analysis of the Choice Between Enterprise and Personal Liability for Accidents, 70 CaLIF. L. REV. 1345 (1982); Kraakman, Gatekeepers: The Anatomy of a Third-Party Enforcement Strategy, 2 J.L. EcoN. \& ORG. 53 (1986); Kraakman, Corporate Liability Strategies and the Costs of Legal Controls, 93 Yale L.J. 857 (1984); Landes \& Posner, Joint and Multiple Tortfeasors: An Economic Analysis, 9 J. Legal StUd. 517 (1980); Stone, The Place of Enterprise Liability in the Control of Corporate Conduct, go YALE L.J. I (1980); Sykes, The Economics of Vicarious Liability, 93 YALE L.J. 123I (1984).

2 See infra Part II.

3 Restatement (SECOND) OF AgENCY $\$ 229$ comment a (1958).
} 
This Article provides an economic analysis of the "scope of employment" rule and related legal doctrines that have evolved to limit vicarious liability in various contexts. Part I develops the theoretical framework by interweaving the economic theory of incentive contracting in principal-agent relationships with the economic interpretation of causation requirements in tort law. Part II applies this framework to a discussion of the two types of tort cases in which the scope of employment is most frequently litigated: "frolic and detour" cases and intentional tort cases. The objective of the analysis is to determine whether the existing disposition of cases tends to promote economic welfare, and, when it does not, to suggest how the law might be modified to that end. Part $I I$ also addresses the limited duty of an employer to control employees' conduct that falls outside the scope of their employment and the related line of "negligent hiring" cases. Part II concludes that existing tort doctrine is often consistent with the pursuit of economic welfare but that the law sometimes focuses on factors that are irrelevant to this goal. Accordingly, Part II suggests a number of modifications to existing legal rules.

Part III adapts the theoretical framework developed in Part I to analyze the liability of a motor vehicle owner for the tort of someone who borrows the vehicle, the liability of a premises owner for the tort of an intruder, and the liability of an employer for the sexual harassment of one employee by another. Like Part II, Part III concludes that the approach of current law to these issues is often reasonably efficient but that several aspects of existing doctrine should be modified.

\section{ECONOMIC PRINCIPLES}

The analysis throughout this Article contemplates the choice between a rule of personal liability, under which the employee alone is liable for his wrongs, ${ }^{4}$ and a rule of vicarious liability, under which the employer and employee are jointly and severally liable. The objective of the analysis is to identify the circumstances under which each rule is "efficient" - that is, the circumstances under which each rule best promotes economic welfare. The concept of economic welfare that underlies the analysis is by now familiar: liability rule A will be said to be "efficient" relative to liability rule B if rule A is potentially Pareto superior to rule B from the perspective of society as a whole. 5

\footnotetext{
4 The use of masculine pronouns throughout is for convenience only and is not intended to convey any assumption about gender identity.

5 This measure of economic welfare is sometimes known as the "potential compensation test," which serves as the basis for much of the modern literature on applied welfare economics and cost-benefit analysis. Conceptually, the test inquires whether those who benefit from a change
} 


\section{A. The Efficiency of Vicarious Liability for Employment-Related Wrongs}

In most cases in which an employee commits a tort during the ordinary course of duties, no question arises as to whether the employee acted within the scope of employment. The wrongful conduct is plainly a consequence of the employment relationship and represents the materialization of a risk that is normally attendant upon such employment relationships.

The efficiency of imposing vicarious liability on the employer under these conditions has been studied at some length. In a previous article, ${ }^{6} \mathrm{I}$ analyzed the choice between personal liability and vicarious liability for torts clearly within the scope of employment and developed several principles for assessing which rule best promotes economic welfare. Because these principles also bear upon the efficiency of vicarious liability in cases in which the scope of employment is in question, it is useful to summarize them here. ${ }^{7}$

I. The Significance of the Choice Between Personal Liability and Vicarious Liability. - Economic theory suggests that between any employer and employee there exists an optimal allocation of the risk of financial loss attendant upon any judgment against the employee. This allocation must take into account each party's attitude toward risk-bearing, the employee's incentives to avoid whatever conduct might lead to a judgment against him, and the incentives available to the employer to monitor the employee or otherwise to guard against the occurrence of a wrong.

If the assumption of liability by the employer is efficient from the perspective of the employer and the employee, and the employer agrees to bear all or part of the risk of a particular judgment, that agreement represents part of the employee's total compensation package, and other components of total compensation are reduced commensurately. In general, the employer will agree to bear all or part of the risk of a judgment if and only if the expected cost to him of doing so (including perhaps a risk premium if the employer is risk averse) is less than the reduction in the other components of the

in policy can compensate those who suffer and still remain better off themselves. Thus, any change in policy that satisfies the test is potentially Pareto superior - if compensation is actually paid to those who suffer, no one will be worse off than before and some will be better off. See H. Varian, Microeconomic ANalysis 2 I8 (Ist ed. 1978). All technical problems with the measure, such as its possible circularity in exceptional cases due to wealth effects, are assumed away. The use of the potential compensation test is now quite routine in economic studies of tort law. See, e.g., W. Landes \& R. Posner, The Economic Structure of Tort Law i617 (1987).

6 See Sykes, supra note $\mathrm{I}$.

7 For a complete exposition of these results, see id. at $1233-59$. 
employee's compensation package that the employee will accept in exchange for the employer's promise.

Absent transaction costs for private risk-allocation agreements, the optimal allocation of risk does not depend upon where the law initially places liability. If the employer would bear the risk in an optimal agreement but a rule of personal liability prevails, then the employer and the employee will contract voluntarily for the employer to reimburse the employee in the event of a judgment. On the other hand, if the employee would bear the risk in an optimal agreement but a rule of vicarious liability prevails, then the employee will contract to reimburse the employer for any amount that the employer pays to a successful plaintiff.

In short, regardless of who bears liability initially, private contracting between the employer and the employee can ensure that the ultimate liability of each party accords with the optimal allocation of risk. Such analysis suggests that the choice between a rule of personal or vicarious liability may be unimportant. ${ }^{8}$

This conclusion rests, however, upon two critical assumptions. First, it assumes that the sum of the payments to the plaintiff by the employer and the employee is the same under both rules of liability. If the plaintiff's judgment exceeds the employee's assets, however, as may often be the case, then the plaintiff will collect more under vicarious liability. Private contracting cannot achieve the same allocation of risk under either liability rule in these circumstances because the magnitude of the risk to be allocated changes with the liability rule. Either the employee, the employer, or both the employer and employee must pay more under vicarious liability.

Second, as suggested at the outset, the proposition that the choice of liability rule does not affect the ultimate incidence of liability depends upon an assumption that the transaction costs of negotiating and enforcing a private risk-allocation contract are small enough to permit the employer and the employee profitably to enter into such a contract. In fact, the costs of risk-allocation agreements may be considerable, and a reallocation of liability by contract thus may be infeasible or at least quite costly.

Hence, the choice between vicarious liability and personal liability is a significant one whenever the employee is unable to pay judgments in full under a rule of personal liability or the costs of negotiating and enforcing a private risk-allocation contract between the employer and the employee are significant. Both circumstances arise frequently in practice and, as suggested below, both lead to significant inefficiencies under personal liability that vicarious liability sometimes will eliminate.

8 This proposition is also developed in some detail in Kornhauser, supra note $\mathrm{I}$, at 1347 , I357-61. 
2. The Potential Inefficiencies of Personal Liability. - Assume for the moment that the employee's tort is not related to any voluntary business transaction with the employer's business (thus, for example, the victim is not a customer or a fellow employee). This assumption ensures that the probability of a tort will not affect consumer willingness to pay for the goods and services of the enterprise and will not affect the wage demands of fellow employees. I will relax this assumption below as required.

The possibility that employees may be unable to pay judgments against them in full creates three possible inefficiencies under a rule of personal liability. First, because the employee does not bear the full (expected) cost of his wrongs, his incentive to avoid committing a wrong, either accidentally or intentionally, often (though not always ${ }^{9}$ ) will be inefficiently small. As a result, the incidence of wrongdoing increases to an inefficiently high level.

Second, because the employer's business does not bear the full cost of the compensable wrongs attendant upon its operation ${ }^{10}$ (either directly through liability payments or indirectly through wages paid to employees who make liability payments ${ }^{11}$ ), its profitability is inflated relative to what it would be if the employee could pay judgments in full. In a competitive market, the employer is then likely to expand production beyond the socially optimal level because his private marginal costs of production are lower than the social marginal costs of production. ${ }^{12}$

${ }^{9}$ Conceivably, even if an employee cannot pay judgments in full, the prospect of a judgment that would exhaust his assets might motivate an inefficiently high level of care. Specifically, a highly risk-averse employee may exercise great care to avoid bankruptcy and might exercise more care than would be cost effective if, for example, all liability were efficiently allocated to a risk-neutral employer.

${ }^{10}$ As Coase recognized long ago, however, injuries are also a cost of victims' activities. See Coase, The Problem of Social Cost, 3 J.L. \& Econ. I (I960). This fact and its implications for the choice between personal and vicarious liability are discussed at length at pp. 579-8I below.

11 This problem does not arise if employees can pay judgments in full, because employees will then bear the full costs of compensable wrongs either directly or indirectly. Obviously, employers do not pay judgments directly under a rule of personal liability unless they agree to "insure" their employees against liability. If an employer does not provide such "insurance," however, employees will take that fact into account in choosing among alternative employment opportunities. Employees will then require higher wages to accept positions that require them to bear a greater risk of liability, and employers will bear costs of liability indirectly through wage payments. If employees can pay all judgments against them in full, their wage demands will reflect the full expected value of prospective liability judgments. Business enterprises will then fully internalize the expected costs of liability through wage payments even if liability judgments are fully paid by employees and transaction costs preclude express bargaining between employers and employees over the allocation of the risk of judgments against the employees.

12 The social marginal costs of production include all marginal costs to the enterprise labor, materials, liability judgments paid, and so on - plus the marginal costs of wrongs to injured parties that are properly attributable to the business enterprise but that go uncompen- 
Third, when employees are potentially insolvent, they may be dissuaded from entering optimal risk-allocation agreements with their employers. An effective risk-sharing agreement requires the employer and the employee to pay the full value of the judgment against the employee, which clearly reduces their expected wealth relative to a regime in which part of the judgment goes unsatisfied. ${ }^{13}$ The existence of this added "cost" to risk-sharing may dissuade risk-sharing - indeed, it may motivate employers to seek out insolvent employees to bear the risk of dangerous activities - despite the fact that the employer is often the better risk bearer. ${ }^{14}$

In addition to these three inefficiencies, inefficiencies may arise under a rule of personal liability even when employees are able to pay all judgments in full if there are significant costs to employers and employees in negotiating and enforcing risk-allocation agreements. Specifically, if the employer is the better risk bearer, such costs may prevent the employer from assuming the risk of judgments against the

sated. Part I.B. below considers the issue of which costs are "properly attributable" to the enterprise. See infra pp. 57I-79.

${ }^{13}$ Suppose, for example, that the employer is risk neutral and the employee is risk averse. Suppose further that the probability of the tort is 0.1 and that this probability cannot be reduced through precautionary measures by the employee - there is no moral hazard problem if the employer assumes the risk of liability. If the employee could pay all judgments in full, optimal risk-sharing would then require the employer to assume the risk of liability in its entirety to shield the risk-averse employee from any prospect of an adverse judgment. The employer would be compensated by the opportunity to reduce wages by an amount greater than or equal to the actuarial value of the risk that he assumes.

Suppose, however, that the potential liability of the employee is $\$ 1$ million and that the employee has only $\$ 10,000$ in assets. To provide the risk-averse employee with protection against loss of his assets in the event of an adverse judgment, the employer must agree to pay not $\$ r 0,000$, but $\$ 1$ million. The first $\$ 990,000$ assuredly will go to the plaintiff, and only amounts in excess of that will provide the employee with protection from the prospect of insolvency. In effect, if the employer is to offer insurance to the risk-averse employee, he must also offer insurance to the plaintiff. (This discussion properly assumes that the employee cannot obtain a discharge in bankruptcy and then collect an insurance payment from the employer the prospective payment from the employer would be treated as an asset by the bankruptcy court and could not be withheld from the plaintiff). Yet only the employee can compensate the employer for insurance through a wage reduction, and the amount of compensation that he will offer may be far short of that necessary to justify the insurance.

In this example, the expected payment from the employer to the plaintiff under an insurance arrangement to protect the employee against the loss of his $\$ 10,000$ would equal $(0.1) \times \$ 1$ million $=\$ 100,000$. Hence, the employer could only come out ahead if wages fell by more than $\$ 100,000$, but that amount probably exceeds the total wages of the employee and far exceeds anything that he would be willing to pay for $\$ 10,000$ worth of insurance.

14 Other things being equal, the employer is likely to be the better risk bearer if he can more readily insure against the risk of liability; if he can diversify the risk by virtue of a large pool of employees who each present similar risks; or if he is a corporation as to which the risk of judgments against employees is a diversifiable risk for the stockholders. The employer may also be a better risk bearer simply because the employer is wealthier than the employee and thus may be less averse to risks of a given magnitude. 
employee that exist under personal liability. Alternatively, the employer and the employee will have to incur the costs of an agreement to shift the risk of liability to the employer.

3. The Effects of Vicarious Liability. - Vicarious liability reduces or eliminates some of the inefficiencies that can arise under personal liability. ${ }^{15}$ First, because vicarious liability, ensures that any judgment against the employee will be paid to the limit of the combined assets of the employer and the employee, any inefficient expansion of the scale of business activity that results when the employee cannot pay judgments is avoided, or at least lessened. Second, vicarious liability often will improve the efficiency of risk-sharing by eliminating the incentive that may exist under personal liabilty to leave liability on the employee in order to take advantage of his inability to pay judgments. Moreover, if the employer is the better risk bearer, vicarious liability can eliminate transaction costs that the employer and the employee might otherwise incur in negotiating and enforcing a private agreement under which the employer assumes the risk of liability.

The ultimate efficiency or inefficiency of vicarious liability also depends, however, on its effect upon employees' incentives to avoid wrongful conduct. The effect of vicarious liability on such incentives depends in turn upon the devices available to the employer to induce careful behavior and the costs of those devices.

One such device is direct observation of the employee's activities. If the employer can cheaply observe precautionary behavior (or deliberately tortious behavior) by each employee, the employer can simply announce a desired standard of conduct, observe subsequent employee behavior, and penalize employees who fail to meet the desired standard. ${ }^{16}$ This type of incentive system is usually inexpensive to design

15 As noted above, this discussion is limited to wrongs against parties outside the employment relation whose injury is not related to any voluntary business transaction with the employer's business. The analysis can easily be extended to other types of injuries, such as injuries to customers or fellow employees. See Sykes, supra note I, at 1256-59.

For example, suppose that employees occasionally commit torts against customers of their employers. If customers are fully informed ex ante about the probability of a tort and the prospects of compensation at each business and take that information fully into account in their purchase decisions, then their willingness to pay for the goods and services of each business will adjust perfectly to reflect the prospect of an uncompensated injury. Businesses will then be unable to externalize liability by employing judgment-proof agents. The efficiency of vicarious liability will therefore depend primarily upon whether it improves risk allocation between the employer and the employee in the presence of transaction costs. See id. at 1258 .

By contrast, if customers have no information about the risk of torts associated with their voluntary business transactions, their willingness to pay will not reflect risks of uncompensated injury. The existence of the customer relationship is of no signficance to the analysis of vicarious liability in such cases. See id. at 1257.

Various intermediate cases of "imperfect information" may also be postulated. For analysis of the information conditions in particular settings and their implications, see Parts III.B. and III.C. below.

16 For example, suppose that injuries at a construction project can be easily avoided by the 
and to implement (assuming that observation is inexpensive) and often provides the employer with the ability to avert employee misconduct altogether.

The employer's influence over advancement and compensation decisions often provides another important incentive device. If the employee desires a long-term relationship with the employer, the employer can exploit this desire through policies under which the employee's prospects for advancement and pay raises, and even the employee's continued employment, depend in part upon the employee's avoidance of any misconduct that might result in harm. Such incentives are also fairly inexpensive to implement in many cases ${ }^{17}$ and, as long as the employee values the employment relationship, these incentives can act as an effective constraint on the employee's behavior even if the employer cannot cheaply observe that behavior. Moreover, because these incentives affect the employee's current and future stream of earnings, they may motivate the employee to avoid wrongful conduct better than the prospect of a liability judgment, which will only be paid to the limit of the employee's current assets (if the judgment is dischargeable in bankruptcy).

The ability of the employer to affect the employee's incentives is much more limited, however, when the employee's behavior is not easily observed or when the employee has no interest in maintaining a long-term employment relationship. Under these conditions, perhaps the only device available to dissuade misconduct is the threat of an indemnity action against the employee in the event that the employer incurs vicarious liability. Such actions can be quite costly to pursue, however, and may not be cost effective if the employee's assets are modest. ${ }^{18}$ When the threat of an indemnity action is the only device for the maintenance of incentives, therefore, a rule of vicarious liability actually may reduce employees' incentives to avoid wrongful conduct and reduce economic welfare. ${ }^{19}$

erection of a barricade to shield an excavation. Knowing the need for such a precaution, the employer can simply order employees to erect it and observe whether or not they comply. Such an observation will usually require little expenditure of time or effort by the employer.

17 See Sykes, supra note 1 , at $1253-55$.

${ }^{18}$ The limited empirical evidence suggests that the employer's right to indemnity is rarely exercised. See Sykes, supra note I, at 1243 . Whether this may reflect an optimal assumption of risk by employers or the costs of indemnity actions is difficult to determine.

${ }^{19}$ If an employee's assets are too meager to justify the pursuit of indemnity by the employer under vicarious liability, then a prospective plaintiff may also find it unprofitable to bring suit under personal liability. If so, then the imposition of vicarious liability will not dilute the employee's incentives to avoid wrongdoing. Plaintiffs may find it worthwhile to file suit, however, even if the employer does not. Unlike the employer, the plaintiff may have an emotional or dignitary interest in filing an action. Alternatively, the employer may decline to pursue indemnity in order to avoid the disruption of otherwise amicable relations with the workforce - an indemnity action that sends an employee into personal bankruptcy could send 


\section{B. The Causal Relation Between Business Activity and Employee Wrongs}

The analysis to this point has assumed that the wrong committed by the employee is properly viewed as a cost of the employer's business. For example, the proposition that the evasion of liability judgments by an insolvent agent may lead to an inefficient expansion in the scale of business activity clearly rests on this assumption or, to put it slightly differently, on an assumption that the business is the "cause" of the wrongs that lead to the judgments. These notions warrant further elaboration.

I. A Definition of "Enterprise Causation." - The legal meaning of the term "cause" depends upon context. In tort law, for example, one often distinguishes "cause in fact" from "proximate cause" and other forms of "causation," 20 and a variety of definitions exist for each concept. ${ }^{21}$

This Section introduces a definition of causation that captures the relationship between the existence of an employer's business and the occurrence of a wrong by an employee. To distinguish this concept of causation from similar concepts in the law and in the literature, it will be termed "enterprise causation."

Initially, it is necessary to define the term "wrong" as it is used in the analysis that follows:

Definition: A "wrong" is an injurious act that leads to liability of a given magnitude.

For example, a particular act of negligence that a person commits while driving a motor vehicle, resulting in a tort that creates liability of $\$$ I million, might constitute a "wrong."22

a signal to the workforce that the employer has little interest in the personal welfare of his employees, affecting morale and productivity adversely.

Finally, even if an indemnity action is worthwhile for the employer, such actions are costly. Also, vicarious liability adds an additional party to litigation and thus may increase litigation costs significantly. Unless these costs are offset by some other benefit of vicarious liability, a shift from personal liability to vicarious liability will reduce economic welfare.

${ }^{20}$ See e.g., W. Keeton, D. Dobbs, R. Keeton \& D. OWen, Prosser and Keeton on The LAw OF ToRts 263-32I (5th ed. I984) [hereinafter Prosser \& KeEton].

21 For a recent survey of the causal inquiry, see Wright, Causation in Tort Law, 73 Calif. L. REV. I 735 (1985).

22 Such a definition of "wrong" is to be distinguished from narrower definitions that, for example, might distinguish among otherwise identical "wrongs" according to the identity of the victim or to the time and place at which the wrong occurs, and from broader definitions that might not, for example, distinguish among wrongs according to the magnitude of liability.

This definition is chosen because the analysis to follow focuses on the degree to which the employment relation affects the expected social costs of torts. To capture those effects, it is useful to consider the effect of the employment relation on the probability distribution of each possible "wrong" as here defined. 
The remaining definitions capture the "causal" connection between the existence of the employment relation and the occurrence of employees' wrongs. The crucial variable in this analysis is the extent to which the employment relation increases the probability of each wrong.

Definition: An enterprise "fully causes" the wrong of an employee if the dissolution of the enterprise and subsequent unemployment of the employee would reduce the probability of the wrong to zero. ${ }^{23}$

For example, consider the case of a service station attendant who negligently performs improper repairs on a customer's vehicle, resulting in an accident and a judgment against the attendant. The accident is fully caused by the service station enterprise under the above definition if the dissolution of the service station enterprise and the subsequent unemployment of the attendant would reduce the probability of an accident attributable to negligent repairs by the attendant to zero.

By contrast, suppose that the same attendant occasionally commits acts of wife-beating and that the incidence of such acts bears no relation to the attendant's employment or unemployment. Then, the tort of wife-beating is not caused by the service station enterprise, because its dissolution and the employee's subsequent unemployment would not reduce the probability of the tort.

To be sure, intermediate cases exist. The probability of wifebeating, for example, might be increased by certain stressful occupations. Such cases motivate a further refinement of the definition of enterprise causation.

Definition: An enterprise "partially causes" the wrong of an employee if the dissolution of the enterprise and subsequent unemployment of the employee would reduce the probability of the wrong but not eliminate it.

One component of the definitions of both full and partial enterprise causation is the "subsequent unemployment" of the employee after dissolution of the enterprise. Thus, to assess enterprise causation in the service station example above, one assumes that after the dissolution of the service station agency the attendant does not go to work for another service station or open his own repair business.

23 This definition of causation is closely related to the concept of "probabilistic causation" developed in Shavell, An Analysis of Causation and the Scope of Liability in the Law of Torts, $9 \mathrm{~J}$. LEGAL STUD. 463, 468-69 ( 980 ), and to the analysis of causation developed in Landes \& Posner, Causation in Tort Law: An Economic Approach, I2 J. Legal Stud. Io9 (1983). Calabresi was perhaps the first to suggest the economic signficance of probabilistic notions of causation. See Calabresi, Concerning Cause and the Law of Torts, 43 U. CHI. L. REv. 69 (I975). 
To be sure, if the service station agency were in fact to dissolve, the employee might well move to a position with another employer. The probability of wrongful behavior in that new position (whether or not in the same line of business) might be less than, equal to, or greater than the probability of wrongful behavior in the former position. Nonetheless, the appropriate benchmark for the comparison of probabilities in the analysis to follow is the subsequent unemployment of the employee. That comparison is the appropriate one because, as the economic discussion will indicate, the efficiency of resource allocation is enhanced if each business enterprise bears the incremental social costs associated with its operation. By measuring those incremental costs with reference to the social costs that would otherwise arise if the resources used by the enterprise were unemployed, a resulting competitive equilibrium will tend to generate an efficient allocation of resources among alternative enterprises and alternative (nonenterprise) uses for the resources (such as leisure). ${ }^{24}$ To be sure, this proposition is subject to a number of caveats relating to the theory of the second-best, many of which are linked to matters discussed below (cost externalization due to insolvency, the infeasibility of cost internalization by both injurers and victims, and so on). ${ }^{25}$

Note finally that the definitions of full and partial enterprise causation leave open the possibility that the dissolution of the enterprise and subsequent unemployment of the employee may increase the probability that the former employee will commit some other wrong. ${ }^{26}$

2. The Implications of Enterprise Causation. - (a) Passive Victims. - Assume initially that the victims of wrongs are "passive," in the sense that they cannot or will not take cost-effective measures to protect themselves against wrongs either by adopting precautions or by curtailing activities that might expose them to potential wrongdoers. ${ }^{27}$ The importance of enterprise causation may now be illus-

24 To give a simple example that suggests why the "subsequent unemployment" benchmark is appropriate, suppose that an individual will commit a wrong that causes $\$ 10,000$ worth of harm with probability o.I if he is unemployed. If he is employed by either Sears or Wards, the probability of the same wrong rises to 0.2. Thus, if the individual is hired by either company, an incremental social cost of (0.2-0.1) $\times \$ 10,000=\$ 1,000$ results from his activities as an employee. If his employment is to be economically efficient, it must generate enough value to cover this cost in addition to his wages and all other costs of hiring him. Yet if the incremental costs of wrongs by workers at Sears were measured with reference to the probability of wrongs by workers at Wards, one would conclude that these incremental costs were zero the probability of the wrong is the same at either company. And if, as a result, neither Sears nor Wards were required to bear the $\$ 1,000$ incremental cost associated with hiring the worker, both would tend to hire an inefficiently high number of employees and to expand to a point at which the social marginal costs of their activities exceeded the social marginal benefits.

${ }^{25}$ See infra pp. 579-8r.

26 The implications of this possibility are explored in note 34 below.

27 This assumption is relaxed below. The analysis in this Section encompasses instances in which victims cannot take measures to reduce their exposure to injury; instances in which it is 
trated with variations on the following hypothetical. An enterprise produces a good that many consumers value well in excess of its marginal capital, labor, and materials costs. The good is priced competitively, thereby yielding substantial consumer (and perhaps producer) surplus. Suppose, however, that some of the employees who produce the good tend to commit assaults that result in civil liability. By hypothesis, neither the probability that an employee will commit an assault nor the magnitude of the resulting liability depends upon the employee's wealth, upon whether he is employed or unemployed, or upon any characteristic of his employment. In addition, by hypothesis, no incentive mechanism exists that would enable the employer to reduce the incidence of employee assaults.

To hold the employer vicariously liable for such employee assaults, regardless of when or where they occur or the identity of the assault victim, is almost certainly inefficient. The employer cannot affect the number of assaults or the total amount of damages. Thus, to the extent that vicarious liability imposes additional costs on the enterprise, it may drive the enterprise out of business or at the very least cause it to shrink as the marginal costs of production increase. Society then will lose at least some of the economic surplus from the production of the enterprise. ${ }^{28}$

Employers might recoup some of their losses through indemnity actions, and when they did not, the costs of vicarious liability to the employer would be mitigated by a decline in the wages paid to employees - if an employer were forced to "insure" his employees against liability for assaults that are unrelated to the enterprise, employees would reduce their wage demands by the expected value to them of the "insurance" provided by their employers. In a perfectly informed labor market in which employees could pay all judgments against them, and neglecting the effects of risk aversion, this reduction in wage demands would result in a wage that was lower by precisely the expected value of the liability borne by the employer. The marginal costs of production would be unaffected, and no loss of surplus would arise.

This conclusion, however, assumes away the familiar problems of employee insolvency and transaction costs. Employees who cannot

inefficient for victims to take such measures; and instances in which victims, because of "bounded rationality" (for example, a failure to perceive the risk of injury or the opportunity to take precautionary measures), systematically neglect the opportunity to reduce their exposure to injury.

${ }^{28}$ One caveat relates to the possibility that vicarious liability provides risk-sharing benefits that are unattainable in its absence due to transaction costs. Although it seems highly improbable, because of the moral hazard problem, that an optimal risk-allocation agreement between the employer and the employee would call for the employer to assume liability for the employee's assaults, it is conceivable that employers are better risk bearers than assault victims. Vicarious liability might then enhance the efficiency of risk-sharing when employees are judgment-proof. 
pay judgments in full may not value "insurance" provided by employers at its full expected cost to the employer. Their wage demands thus will not fall by the full expected value of the "insurance," and a decline in wages will not fully compensate the employer for increased liability. In addition, as noted above, various transaction costs tend to increase when employers are held vicariously liable, and these costs will add to the marginal costs of production. Hence, the imposition of vicarious liability under the circumstances hypothesized here appears inefficient because it leads to higher costs of production, higher prices, and a loss of consumer and producer surplus, but in no way reduces the expected costs of employee misconduct.

This analysis suggests the general proposition that vicarious liability for a given wrong is probably inefficient if (a) the enterprise does not cause the wrong, even partially; and (b) the enterprise cannot reduce the probability of the wrong through incentive contracts with its employees. ${ }^{29}$

A second proposition can be illustrated with a slight modification of the above hypothetical. Continuing with the assumption that the employer cannot reduce the incidence of assaults through incentive devices, suppose that the employee is more likely to commit assaults in the workplace than elsewhere, so that his employment increases the probability that an assault will occur. The probability of a wrong thus depends upon whether the employee is employed or not, but (by hypothesis) cannot be affected by the employer once the employee has been hired. An employee with an intrinsically stressful job may be more likely to commit an assault, for example, but the employer's only effective means of reducing the probability of an assault may be to terminate the employment relationship.

In this situation, it is inefficient to impose vicarious liability on the enterprise for the full value of the wrong, because the scale of the enterprise's activity will tend to contract excessively. Yet it is also inefficient to allow the enterprise to escape liability altogether - if the employee is insolvent, the resulting scale of enterprise activity will be excessive. Efficient resource allocation thus requires the enterprise to bear liability for part, but not all, of the cost of the wrong. ${ }^{30}$ If

${ }^{29}$ Previous writers have suggested similar propositions, but without considering the availability of effective incentive devices. See Calabresi, Some Thoughts on Risk Distribution and the Law of Torts, 70 YALE L.J. 499, 514 (1961) (arguing that "resource allocation militates strongly against allocating to an enterprise costs not closely associated with it"); Smith, Frolic \& Detour, I923 Colum. L. REv. 444, 46r (suggesting that an enterprise should bear risk only if the enterprise is a contributing factor).

30 Although the computation of the appropriate judgment against the enterprise may be complex (perhaps infeasible) in practice, it is conceptually straightforward - the value of the judgment against the employer must ensure that the enterprise directly or indirectly bears a cost of production with an expected value exactly equal to the increment in the expected value of the wrong attributable to the enterprise. 
the imposition of partial liability is infeasible for institutional reasons - if vicarious liability must be imposed on an all or nothing basis then the liability rule is inevitably "second-best." Other things being equal, the greater the extent to which the employment relation "causes" the wrong, the more likely it is that vicarious liability for the entire judgment will be second-best efficient. ${ }^{31}$

A third proposition may be illustrated with a further variation of the assumptions above. Again suppose that the employer cannot reduce the incidence of assaults with incentive devices and that the probability of an assault depends solely upon the employment or unemployment of the employee. Assume further that the probability of an assault would be zero if the employment relationship were dissolved and the employee remained unemployed thereafter. Thus, the enterprise fully causes the assault. It follows that the injury attributable to the assault is a cost that is fully attributable to the operation of the enterprise - the enterprise will operate at an efficient level of output only if it bears, directly or indirectly, all liability for the employee's assault. The imposition of vicarious liability is plainly efficient under these circumstances because, by hypothesis, it can have no adverse effect on the incentives of the employee to engage in tortious conduct.

The analysis becomes more complex if incentive devices can reduce the probability of the wrong or if the assumption of liability by the employer may affect the propensity of the employee to commit the assault. To continue with the previous hypothetical, suppose that the probability of an assault is not directly affected by the employment or unemployment of the employee - and thus the enterprise does not even "partially cause" the assault - but that the employer can reduce the probability of an assault through some appropriate incentive device, for example, by threatening to discharge the employee if he commits an assault or by observing the employee's behavior in advance of an assault and intervening to prevent the assault before it occurs. Obviously, the employer has no reason to use such an incentive device under a rule of personal liability. The question thus arises whether vicarious liability may enhance economic welfare even though the enterprise does not cause the wrong.

31 Formally, to determine the second-best rule in a competitive market, one must weigh the loss of economic surplus under personal liability (owing to the fact that the social marginal costs of production would exceed the private marginal costs of production, which would result in an equilibrium market price below social marginal costs) against the loss of surplus under vicarious liability (owing to the fact that the private marginal costs of production would exceed the social marginal costs, which would result in an equilibrium market price that exceeded social marginal costs). Of course, this "second-best" rule may well be impossible to identify in practice, at least on a case-by-case basis. Probably the best that can be done is to choose between vicarious liability and personal liability in general classes of cases, based upon a rough analysis of the economic costs and benefits of each rule. 
To examine this issue, suppose first that the costs to the enterprise of using the incentive device are zero and that the incentive device always prevents the assault - thus, the enterprise never actually pays damages under a rule of vicarious liability. Vicarious liability is clearly efficient under these circumstances, because it eliminates any possibility of an assault at no cost to the enterprise. ${ }^{32}$

Now suppose that the incentive device reduces but does not eliminate the probability of the assault and that the reduction of the expected damages from assaults when the incentive device is utilized exceeds the costs of the incentive device. If the prospective victims knew of their impending assault, they would offer the enterprise, and the enterprise would accept, a side payment to use the incentive device. The marginal costs of production for the enterprise would not increase, and the incidence of assaults would decline with no adverse effect on the level of enterprise activity.

Of course, such side payment schemes are unlikely to arise in practice. In their absence, perhaps the only way to motivate the employer to utilize the incentive device is to hold him liable for any judgment against the employee. Under a strict liability theory, the employer would always incur joint and several liability with the employee. Under a negligence theory, the employer could avoid liability with a showing that the assault occurred despite the fact that he utilized the appropriate incentive device.

Usually, vicarious liability in employment relationships (conventional respondeat superior liability) is "strict" - the employer cannot successfully defend the action by proving that he exercised all reasonable means to dissuade the employee from committing the wrong. ${ }^{33}$ In the present hypothetical, strict liability will indeed induce the employer to utilize any and all incentive devices that are cost effective in reducing his liability. Because the employer is not compensated for the costs of the incentive devices as he would be under an idealized side-payment scheme, however, and because he bears liability for judgments against the potentially impecunious employee, the marginal costs of production for enterprise output increase and the scale of enterprise activity contracts to a point at which the prevailing price exceeds the social marginal costs of production. To determine whether vicarious liability has reduced or enhanced economic welfare, the resulting loss of consumer and producer surplus must be weighed against the reduction in the expected value of losses from assaults. The welfare effects of vicarious liability are more favorable the greater

32 If workers value the opportunity to commit assaults and incorporate this factor into their wage demands, however, or if monitoring behavior by employers imposes some disutility on the workforce, workers may require higher compensation from enterprises that discourage assaults. To this extent, no incentive device may be costless from the perspective of the employer.

33 See Prosser \& KeEtoN, supra note 20, at 50I-02. 
the degree to which the incentive device reduces the probability of assaults and the lower the costs to the enterprise of implementing the incentive device.

An alternative approach to employer liability, as noted, is to impose liability on the employer only if he is negligent and fails to use the desired incentive device. Hereafter, this policy will be termed "vicarious liability based on negligence" - a term that may suggest that liability is not really vicarious at all, but that I employ here for expositional convenience. In the present hypothetical, this approach is unambiguously superior to strict vicarious liability, because the employment of the tortfeasor does not increase the probability of the wrong, and hence the associated liability is not properly included in the social marginal costs of enterprise production. If the costs to the enterprise of using the incentive device are significant, however, the welfare consequences of vicarious liability based on negligence are still ambiguous. Although the enterprise escapes liability if it uses the incentive device, the costs of using it will become part of the marginal costs of production for the enterprise. Price will rise and consumer and producer surplus will fall. Again, to determine the net effect on social welfare, this reduction of surplus must be weighed against the benefits of the incentive device to potential assault victims. Other things being equal, the lower the cost of using the incentive device, and the greater its effectiveness, the more favorable are the welfare effects of vicarious liability. ${ }^{34}$

The analysis developed above also applies, with only minor modifications, to vicarious liability outside the employment relationship. Whenever an individual or business can dissuade wrongdoing at little or no cost through the adoption of incentives that affect the behavior of potential wrongdoers, ${ }^{35}$ the imposition of vicarious liability can

34 One final complication relates to the possibility that unemployment may be the "cause" of certain types of wrongs. Specifically, workers who are unemployed may commit any number of intentional or accidental wrongs, the probability of which declines or disappears once they are employed. The employment relationship thereby creates a social benefit for which employers may not be compensated: in an ideal world, employees' wage demands would be reduced to the extent that their employment eliminates the possibility of certain liability judgments against them. Employers thereby would be "compensated" for this ancillary benefit of employment. Even if employees take such factors into account in their wage demands, however, those demands will not fall by the full amount of the expected liability averted by employment if the employees cannot pay judgments against them.

Clearly, such a benefit is difficult to incorporate into the design of a liability rule, but its existence may in some cases weigh against the imposition of vicarious liability because vicarious liability will increase the costs of production for business enterprises and lead to a reduced level of production and employment.

35 For a slight variation in the analysis, suppose that an employer has advance notice that his employee is about to commit a murder and can avert the murder by reporting the employee to the police - an arguably inexpensive "incentive device" from the employer's perspective. It probably would be efficient to impose a duty upon the employer to make the report. Of course, 
motivate the adoption of such incentive devices and will be efficient whenever the benefit of reduced malfeasance exceeds the social costs of those incentive devices. ${ }^{36}$ When the "causal" relationship between the activities of the entity subject to vicarious liability and the prospective wrong is weak, however, vicarious liability based on negligence is superior to strict vicarious liability.

The one caveat to this proposition relates to administrative costs, which are an important consideration in any economic analysis of liability rules. One must always be alert to the possibility that one liability rule may be cheaper to administer than another or may tend to produce fewer meritless suits. With respect to the choice between strict vicarious liability and vicarious liability based on negligence, the negligence approach probably leads to incrementally higher administrative costs associated with the need to litigate the employer's negligence, whereas the strict liability approach probably leads to incrementally higher administrative costs associated with a higher number of lawsuits. ${ }^{37}$ The analysis to follow (except where noted) assumes that these costs roughly cancel out, so that the administrative cost factor does not weigh substantially in favor of either regime.

(b) Second-Best Issues: Victims Who Are Not Passive. - Suppose now that tort victims can take precautions to guard against being victimized and that they can (and will) curtail whatever activities expose them to the possibility of a wrong. Under these assumptions, no conventional tort liability rule can induce both injurers and victims to behave optimally (if the victim is not a party to a voluntary transaction with the business enterprise, as assumed above). ${ }^{38}$

Specifically, either a negligence regime or a strict liability regime, coupled with an appropriate contributory negligence defense or its equivalent, arguably can induce both injurers and victims to take cost-effective precautions during the course of their activities (assuming no insolvency on the part of either). Despite the exercise of such precautions, however, some injuries may occur. The frequency of injuries might be reduced if injurers and victims reduced their participation in activities that create a risk of injury. Indeed, an efficient

there is no reason to limit such a duty to employers; anyone who has advance notice of the prospect of a serious crime, and can avert the crime at little cost to himself by informing the police, arguably should have a duty to inform. The imposition of liability for failure to report is one way, though certainly not the only way, to encourage the desired behavior.

36 To be sure, the value that society places on individual liberty and autonomy may constrain the degree to which vicarious liability is imposed under these conditions. To put it another way, any undesirable infringement of individual liberty and autonomy that might result from the imposition of vicarious liability and the resultant monitoring of some individuals by others is properly viewed as an economic cost.

${ }^{37}$ See, e.g., W. LANDES \& R. PoSNER, supra note 5, at 65-66 (comparing the costs of administering strict liability and negligence standards).

${ }^{38}$ See Shavell, Strict Liability Versus Negligence, 9 J. LEGAL STUd. I (Ig80). 
adjustment in such activity levels will occur on the part of any party who bears the full costs of the injuries that occur despite the exercise of due care. Yet it is impossible (with conventional liability rules) for all parties to bear those costs. Under negligence, victims bear such costs, and injurers avoid them; the opposite result occurs under strict liability. Hence, whichever regime prevails, either victims or injurers will fail to make an efficient adjustment in their activity levels. ${ }^{39}$

As a result, the choice between strict liability and negligence is an exercise in "second-best" analysis. If it is more efficient for injurers to internalize losses when everyone exercises due care, a rule of strict liability with a contributory negligence defense is superior; if it is more efficient for victims to bear losses when everyone exercises due care, a rule of negligence with a contributory negligence defense is superior. ${ }^{40}$

Related second-best issues arise when the injurer is judgment-proof and a court must decide whether to impose vicarious liability on the injurer's employer - the choice between personal liability and vicarious liability under these circumstances plainly affects the degree of cost internalization by injurers and victims. Putting aside the effects of the liability rule on the efficiency of risk-sharing and precautionary behavior, a rule of personal liability, which induces victims to curtail their activities, may sometimes be more efficient than a rule of vicarious liability, which leads employers to curtail their activities (or their employee's activities). The reverse possibility also exists if it is more efficient for employers to reduce activities than for victims to do so.

Thus, once the assumption of passivity on the part of victims is relaxed, the choice between personal liability and vicarious liability becomes considerably more complicated if employees are judgmentproof. Vicarious liability then affects the balance of cost internalization by injurers and victims, and it may be quite unclear how this balance should be struck, just as it may be unclear whether negligence or strict liability is the better rule to govern the liability of the employee.

Of course, if employees are able to pay judgments in full, vicarious liability will not affect the amount of compensation paid to victims. ${ }^{41}$ Victims' behavior - their choice of precautions and activity levels -

39 Of course, if "contributory negligence" existed whenever the victim failed to engage in the "first-best" activity level, in addition to those instances in which the victim failed to exercise due care, and if "negligence" existed whenever the injurer failed to engage in the "first-best" activity level, then either strict liability or negligence with a contributory negligence defense might achieve a first-best outcome. Judgments about the first-best activity level are presumably beyond the competence of the courts in all but exceptional cases, however, and ordinarily are not addressed in the analysis of negligence or contributory negligence.

${ }^{40}$ See Shavell, supra note 38.

41 This assumes that the computation of damages will not be affected, for example, by the presence of a "deep-pocket" defendant. 
will then be unaffected by the choice between personal liability and vicarious liability, and the analysis can proceed as if the victims are "passive."

Furthermore, even if employees are judgment-proof, classes of cases arise in which cost internalization by injurers and their employers is clearly more efficient than cost internalization by victims. ${ }^{42}$ In these cases, the analysis can also proceed as if victims are "passive," because the greater degree of cost internalization by employers under vicarious liability is unambiguously beneficial. Alternatively, vicarious liability may considerably improve the efficiency of risk-sharing or the efficiency of precautionary behavior by injurers, and these efficiencies may outweigh any inefficiencies of vicarious liability resulting from reduced cost internalization by victims.

In addition, observe that if the choice between vicarious liability and personal liability does not affect the amount of damages awarded to victims (although it obviously may affect how much of any award they can collect), then vicarious liability results in the same cost internalization by enterprises that cause injuries, and the same cost internalization by victims, that would result if all employees who cause injuries could pay judgments against them in full. Thus, if one supposes that the degree of cost internalization by injurers and victims is roughly efficient when employees can pay judgments in full, vicarious liability is an attractive method of promoting that degree of cost internalization.

Finally, whether or not victims are "passive," and irrespective of the appropriate degree of cost internalization by injurers and victims, the implications of enterprise causation remain much the same. The more the employment relationship contributes to the probability of the wrong, the greater the economic benefits (if any) of strict vicarious liability, other things being equal. Similarly, if the enterprise does not even partially cause the wrong, strict vicarious liability is inferior to vicarious liability based upon negligence. Vicarious liability based upon negligence may in turn be inferior to personal liability, depending upon such factors as the cost and effectiveness of the incentive devices available to the employer.

\section{The Scope of Employment Rule}

The law places agency relationships into several categories, and the rules governing the vicarious tort liability of an employer or "principal" depend critically upon the category into which the agency falls. Most employer-employee relationships are "master-servant" re-

42 For example, victims may perceive the risk of injury as de minimis and thus ignore it in deciding on their activity levels. See infra note 53; supra note 27. 
lationships, in which the master controls or has the right to control the physical conduct of the servant in the performance of the servant's duties. ${ }^{43}$ Absent the requisite degree of control, however, the employee may be classified as an independent contractor or other nonservant agent. ${ }^{44}$ Under the doctrine of respondeat superior, masters are liable for torts that their servants commit within the scope of employment. If the tortfeasor is an independent contractor or nonservant agent, however, with some exceptions, the principal or employer is not liable for the tort. ${ }^{45}$

The discussion to follow focuses upon respondeat superior and specifically upon the scope of employment limitation to the master's liability. The Restatement (Second) of Agency defines the "scope of employment" as follows:

(I) Conduct of a servant is within the scope of employment if, but only if:

(a) it is of the kind he is employed to perform;

(b) it occurs substantially within the authorized time and space limits;

(c) it is actuated, at least in part, by a purpose to serve the master, and

(d) if force is intentionally used by the servant against another, the use of force is not unexpectable by the master.

(2) Conduct of a servant is not within the scope of employment if it is different in kind from that authorized, far beyond the authorized time or space limits, or too little actuated by a purpose to serve the master. ${ }^{46}$

According to the Restatement, masters are not liable for torts committed by their servants outside the scope of employment unless:

(a) the master intended the conduct or the consequences, or (b) the master was negligent or reckless, or (c) the conduct violated a non-

43 See Restatement (Second) of Agency § 2(1)-(2) (1958); Prosser \& Keeton, supra note 20 , at $501-08$.

44 See Restatement (Second) OF Agency § 2(3) (1958); Prosser \& Keeton, supra note 20 , at $509-x 6$.

45 See Restatement (SECOND) of Agency § 219 (1958); Restatement (SECOND) of ToRTS $\S 409$ (1965); Prosser \& KeEton, supra note 20, at 501-16; H. REUSChlein \& W. Gregory, HaNdBook on the Law of Agency and Partnership 99-IO4 (1979); W. Sell, AgenCy 8491 (1975). The economic basis for the distinction between "servants" and "independent contractors," and the basis for the various exceptions to the independent contractor rule, are discussed at length in Sykes, supra note I, at 1259-79.

46 Restatement (SECOND) of AGENCY § 228 (1958); see also id. § 229 (kind of conduct within scope of employment); id. $\$ 230$ (acts forbidden by master); id. $\$ 231$ (criminal or intentionally tortious acts); id. $\S 232$ (failure to act); id. $\S 233$ (time of service); id. $\S 234$ (area of service); id. $\S 235$ (conduct not for purpose of serving master); id. $\S 236$ (conduct actuated by dual purpose); id. $\$ 237$ (re-entry into employment). 
delegable duty of the master, or (d) the servant purported to act or to speak on behalf of the principal and there was reliance upon apparent authority, or he was aided in accomplishing the tort by the existence of the agency relation. ${ }^{47}$

The commentators offer somewhat simpler definitions. ${ }^{48}$ Seavey, for example, suggested that a tort is within the scope of employment if "it can be said rationally that the employment is the primary cause of the tort." 49 According to Prosser and Keeton, the scope of employment encompasses "acts which are so closely connected with what the servant is employed to do, and so fairly and reasonably incidental to it, that they may be regarded as methods, even though quite improper ones, of carrying out the objectives of the employment."

All of these characterizations are somewhat ambiguous and provide only modest insight into the application of the scope of employment rule in practice. To facilitate concrete discussion of the rule and its economic consequences, this Part considers two groups of cases: cases involving torts by servants during a purported "frolic and detour" from their employment and cases involving intentional torts by servants. The analysis concludes with a brief discussion of the duty of a master to control conduct of a servant that is outside the scope of employment.

\section{A. Frolic and Detour}

A "frolic" or "detour" from employment occurs when an employee, while on travel for the employer, deviates from his assigned tasks for personal errands or other personal business. Not surprisingly, most frolic and detour cases involve motor vehicle torts. Thus, it is instructive to review the economic issues that arise with respect to motor

47 Id. § $219(2)$.

${ }^{48}$ In addition to efforts to define the scope of employment, several commentators have advanced suggestions for reform or rationalization of the scope-of-employment limitation. In an article on frolic and detour cases, Smith suggests limiting the scope of employment to a "zone of risk" - vicarious liability would be imposed only if the enterprise is a "contributing cause" of the tort and the deviation from the servant's regular employment that led to the tort was "probable" in light of what the servant was employed to do. See Smith, supra note 29, at 72425, 728. James argues for the imposition of vicarious liability for all reasonably foreseeable risks incidental to the enterprise. See James, Vicarious Liability, 28 TUL. L. Rev. 16I, I7480 (1954). Morris criticizes any limitation of liability to foreseeable risks on the ground that most enterprises purchase insurance; insurance actuaries, Morris suggests, estimate risks by generalizing from the experience of many entrepreneurs with many types of risks, so that the ability of a particular entrepreneur to foresee a particular risk is irrelevant. See Morris, Enterprise Liability and the Actuarial Process - The Insignificance of Foresight, 70 YALE L.J. 554 (I96I).

49 W. Seavey, Handbook of the LaW of Agency i48 (I964).

50 Prosser \& KeEton, supra note 20 , at 502. 
vehicle torts when no issue of enterprise causation is present. ${ }^{51}$ Suppose, for example, that a truck driver negligently causes an accident while making a delivery for his employer. If the driver precisely followed the route suggested by the employer, and undertook no personal business during the trip, then the accident is fully caused by the employer's enterprise. 52

As earlier analysis suggests, the choice between personal liability and vicarious liability is arguably immaterial if the truck driver carries enough insurance to pay any judgment against him in full. The compensable costs of accidents are fully internalized by the enterprise (the truck driver's wages must compensate him for the cost of the insurance necessary to cover on-the-job accidents). Furthermore, vicarious liability will not enhance the efficiency of risk-sharing because the driver's insurance company is at least as efficient a risk bearer as the employer.

In many instances, however, the driver will not have insurance, or the insurance that he does have will be inadequate to pay the judgment in full, particularly if the judgment is large. Vicarious liability then has two obvious benefits. First, it will force the enterprise to bear a greater proportion of the cost of the accidents that it "causes." Second, it will shift risk from the driver and accident victim, who are probably relatively poor risk bearers, to the employer or his insurance company, who are likely to be superior risk bearers.

Even if the employer will not seek indemnity from the employee, vicarious liability is unlikely to reduce significantly the driver's incentives to avoid the commission of motor vehicle torts. The widespread existence of private automobile insurance policies suggests that the efficiencies that accompany the shifting of risk to a superior risk bearer outweigh any moral hazard problem attendant upon insurance for motor vehicle accidents. Similar efficiencies in risk-bearing should arise when the employer "insures" the driver.

One question remains: does reduced cost internalization by victims under vicarious liability, and a resulting inefficient increase in their activity levels as drivers or pedestrians, offset the other benefits of vicarious liability? This result seems improbable, as there is no apparent reason why cost internalization by the victims of motor vehicle torts should be systematically preferred to cost internalization by injurers. Indeed, although cost internalization may induce an efficient adjustment in the activity levels of employees who are potential in-

51 Such issues are discussed at some length in Sykes, supra note I, at 1268-71.

52 That is, if one assumes that unemployed people engage in approximately the same amount of personal driving as employed people, then the incremental probability of injuries in the course of business-related driving done by a truck driver is entirely attributable to the business enterprise. 
jurers, it may have little impact on the activity levels of potential victims acting in their personal capacity. ${ }^{53}$

How does the analysis change if the tort is not "caused" by the enterprise? Suppose, for example, that an employee has an accident while shopping for groceries on his own time over the weekend - an activity clearly unrelated to the enterprise. Under these circumstances, the imposition of vicarious liability would place a cost on the enterprise that was not related to any wrong "caused" by its activities. ${ }^{54}$ The price of the enterprise's goods or services would rise inefficiently, and consumer and producer surplus would decline. Vicarious liability would then be inefficient unless (a) it caused the employer to adopt incentive devices that produced a reduction in the incidence of motor vehicle torts by employees that was substantial enough to offset the inefficiencies of imposing added costs on the enterprise, or (b) it resulted in an increase in the efficiency of risksharing that offset those inefficiencies.

As to possibility (a), it is doubtful that an employer could reduce significantly the number of motor vehicle torts committed by employees on personal business. Obviously, the employer cannot deter such torts cost effectively by observing and correcting negligent behavior in advance of an accident. In addition, because many motor vehicle torts probably are attributable to carelessness or momentary lapse of attention rather than to calculated risk-taking, the ability of an employer to affect substantially the probability of motor vehicle torts through threats of discharge or other such incentives within the employment relationship is quite limited. It thus seems improbable, or at least highly conjectural, that the benefits of a reduced accident rate under vicarious liability would be substantial enough to justify the imposition of added costs on the business enterprise.

With regard to possibility (b), any risk-sharing benefits would also

53 Businesses are interested in overall profitability. The imposition of additional costs on a business will affect profitability and thus affect investment decisions concerning the scale of business activity. Hence, one would expect that cost internalization by businesses, particularly large businesses for which periodic accident liability is highly probable, will have a systematic impact on their activity levels.

In the case of individuals, however, a slightly greater or lesser degree of cost internalization with respect to fairly low-probability events may have little impact on decisionmaking. The activity of walking, for example, may not be greatly affected by the choice between vicarious liability and personal liability, because the slightly greater risk of uncompensated injury (for example, by a negligent driver) under personal liability may be so small that individuals do not consider this risk in choosing whether to walk. If so, then no inefficiencies could arise from the reduction in cost internalization by pedestrians under a rule of vicarious liability; in effect, such victims are "passive."

54 An indemnity action to recover that cost would itself be costly, and thus enterprise costs will increase even with an indemnity action. 
be offset at least in part by the inefficiency of imposing costs on the enterprise that are unconnected to its operation and by added costs of litigation. ${ }^{55}$ Moreover, many (though not all) of the costs of personal injuries are covered by first-party insurance policies and, to that extent, risk-sharing is reasonably efficient even without transferring losses to the employer. Thus, the imposition of vicarious liability probably could not be justified simply as a means of increasing the efficiency of risk-sharing.

The law is basically consistent with this analysis. A motor vehicle tort committed by an employee while on a personal shopping trip on his day off, for example, is unquestionably outside the scope of employment, and his employer will escape liability under the scope of employment rule. ${ }^{56}$ In most reported frolic and detour cases, however, the tort occurs while the employee is on "company time" but is at least arguably engaged in personal business. The analysis of such cases is only slightly more difficult.

For example, assume that an employee runs a personal errand during a business trip and commits a motor vehicle tort during the personal errand. Assume further, however, that the employee would run an identical personal errand on his own time even if he had no affiliation with the employer. Under this assumption, the existence of the employment relationship has no effect on the ex ante probability of the tort. For the reasons given above, therefore, it is probably inefficient to impose liability on the employer. Indeed, in reaction to the imposition of vicarious liability, an employer might attempt to discourage employees from performing personal errands while on company business. Yet society may actually benefit if employers permit employees to perform such errands, because the employee's total company and personal travel will decline, thereby reducing the overall likelihood of a tort, as well as the cost of travel.

On the other hand, some torts committed during personal errands are "caused" by the enterprise. If an agent travels on business to a distant city, for example, and his lack of familiarity with the city streets considerably increases the probability of an accident, any resulting tort is to a considerable extent "caused" by the enterprise.

Hence, the following principle would, in theory, provide a reason-

55 The creation of a social insurance fund to compensate motor vehicle tort victims who cannot recover fully from tortfeasors is probably a superior policy alternative. Such a fund could achieve comparable risk-sharing benefits without the high transaction costs of the tort system (although, to be sure, taxes to finance such a fund might have their own misallocative effects). Such funds already exist to some extent in many states in the form of state-administered "uninsured motorist" funds and are financed in part by a vehicle registration tax on all owners of motor vehicles who fail to present evidence of a minimum level of insurance coverage.

56 See Prosser \& KeEToN, supra note 20, at 503-05. 
ably efficient disposition of the frolic and detour cases involving motor vehicle torts. If a motor vehicle tort occurs during a personal errand of the employee, the employer incurs vicarious liability for the tort only if (a) the tort arose during an errand of the sort that probably would not have occurred absent the existence of the employment relationship, or (b) for some other reason, the probability of the tort was substantially increased by the existence of the employment relationship - for example, the tort occurred because the employee was unfamiliar with the area in which he was required to travel.

The courts' approach to frolic and detour cases, however, is often quite different. In many cases, the courts focus on the length of the detour from the employee's business travel route as the test for vicarious liability - the employer is only liable for torts committed when the employee makes "short" detours. ${ }^{57}$ Such a focus seems inefficient because the relationship between enterprise causation and the magnitude of the departure from an assigned route appears quite weak. An employee may stop for personal business that he would transact anyway without any significant departure from his route, and an employee who travels across country on business may make an extensive detour for sightseeing that he would not undertake absent his business travel. 58

Other courts focus on the foreseeability of the employee's deviation from his route as the test for vicarious liability. 59 This approach might seem reasonable, as employers can hardly undertake to deter behavior that they cannot foresee. Yet it is the foreseeability of the tort that is important to the design of whatever incentives the employer might wish to utilize, not the foreseeability of its location, and motor vehicle torts by traveling agents are almost always foreseeable. More importantly, the degree of enterprise causation bears no apparent relationship to the foreseeability of the employee's detour. Hence, the foreseeability test that is applied in many frolic and detour cases also seems economically unsound.

57 See, e.g., Riley v. Standard Oil Co., 23 I N.Y. 301 , I32 N.E. 97 (r92 I) (imposing vicarious liability for a four-block departure from the assigned route); RESTATEMENT (SECOND) of AGENCY $\$ 234$ (1958). See generally W. SEAVEY, supra note 49, at $15 \mathrm{I}-52$ (discussing various detour cases).

58 To be sure, it may be desirable from the employer's perspective to permit his employees to take short detours while on company time - the benefit to the employee may well outweigh the slight cost to the employer and thereby allow for a more than offsetting reduction in the employee's compensation. Yet the mere fact that the employer implicitly authorizes short detours should not result in liability for accidents that occur in the course of such detours. As noted earlier, that policy may simply motivate the employer to prohibit personal errands on company time altogether, with a resulting increase in the overall likelihood of torts.

59 See, e.g., Kohlman v. Hyland, 54 N.D. 710,2 to N.W. 643 (1926); ProsSER \& KeETON, supra note 20 , at 504-05. 
[Vol. 101:563

\section{B. Intentional Torts}

The basic principles that govern the efficiency of vicarious liability for intentional torts are developed in Part I above, through the various hypotheticals involving employee assaults. ${ }^{60}$ In analyzing the case law with respect to these principles, it is instructive to divide intentional torts by employees into two categories: torts that arise from the employee's purely personal motivations, and torts that occur when the employee acts to serve the principal. This division highlights important distinctions in existing law as well as important distinctions in the effects of vicarious liability on resource allocation.

As to the first category, vicarious liability is likely to be efficient (subject to the usual second-best caveats concerning victims' incentives), even if an intentional tort has a seemingly personal motivation, ${ }^{61}$ when two conditions hold. First, the tort must be "caused," at least in large part, by the employment relationship. Second, the imposition of liability on the employer must not excessively reduce the employee's incentives to avoid wrongful conduct. ${ }^{62}$

The second of these conditions for efficiency is familiar. The first condition, however, requires further discussion. Suppose, for example, that an intentional tort occurs because the existence of the enterprise causes the employee to encounter unusual circumstances that he would not otherwise encounter. Intrinsically stressful occupations, for

60 See supra pp. $573-79$.

61 It is important to recognize that vicarious liability provides fewer risk-sharing benefits in the case of intentional torts than in the case of unintentional torts, because intentional torts involve fewer uncertainties. Specifically, suppose that employees are never held liable for intentional torts that they do not commit, that employees never "accidentally" commit intentional torts, and that the employee can accurately foresee the amount of the judgment that will result from a tortious act. Then, there is no risk to share between the employer and the employee the employee knows that tortious behavior will result in a claim against him in a certain amount and that otherwise no claim will arise. Risk is nonexistent for him because there is a deterministic relationship between his behavior and the judgment.

With respect to potential tort victims, however, risk still exists. Hence, opportunities for beneficial risk-sharing between employers and tort victims may still arise.

62 In one sense, the tortious conduct of an intentional tortfeasor is often "observable" by a vicariously liable employer because intentional torts usually result in judgments against the tortfeasor about which the vicariously liable employer will have knowledge. Indeed, if tortious behavior always leads to a judgment, then the employer's awareness of the existence or nonexistence of a judgment is tantamount to awareness of the existence or nonexistence of tortious behavior. This situation is quite distinct from most unintentional torts; an employee can exceed the speed limit a thousand times, for example, but never have an accident.

The "observability" of the employee's behavior in this sense may not help the employer to deter his torts. A distinction must be drawn between direct observation of tortious conduct and inferential "observation" based on the existence of a judgment. In the latter case, the observation of behavior is necessarily subsequent to the tort. Thus, the employer cannot intervene to discourage the commission of the tort but can only exact an ex post penalty. As discussed earlier, ex post penalties, such as costly indemnity actions, may be quite inferior to ex ante penalties based upon observation of potentially tortious behavior. 
example, may precipitate intentional torts. In such cases, the business enterprise "causes" the tort even though the employee's tortious behavior may evince a purely personal motivation.

Most hornbook statements of the law suggest that vicarious liability will not apply if an agent acts out of personal ill will. Rather, the employee must act out of a purpose to serve the employer. ${ }^{63}$ Recent case law, however, reflects a more flexible approach that appears consistent with the efficiency analysis. For example, one California court upheld the imposition of vicarious liability against a building subcontractor for his drunken employee's assault of two employees of the general contractor. ${ }^{64}$ The court reasoned that the tort resulted from the tortfeasor's perception of his rights as an employee. 65

Similarly, the D.C. Circuit has held that a jury could impose vicarious liability on a trucking company whose deliveryman raped a customer. 66 Crucial to the holding was the court's observation that the deliveryman's "badge of employment" enabled him to secure entry to the victim's premises. ${ }^{67}$ This result appears efficient if one assumes that the probability of a rape was considerably enhanced by the deliveryman's employment status.

Finally, in Ira S. Bushey \& Sons, Inc. v. United States, 68 the Second Circuit affirmed the imposition of vicarious liability upon the Coast Guard for vandalism by a drunken sailor. Observing that "the proclivity of seamen to find solace for solitude by copious resort to the bottle while ashore has been noted in opinions too numerous to warrant citation," 69 Judge Friendly suggested that vicarious liability was appropriate because the tort was caused by the nature of the tortfeasor's employment. ${ }^{70}$

63 See, e.g., Restatement (Second) of Agency § 228 (I958); Prosser \& Keeton, supra note 20, at 505-06; W. SEAvEy, supra note 49 , at 157 .

${ }^{64}$ See Rodgers v. Kemper Constr. Co., 50 Cal. App. 3d 608, 124 Cal. Rptr. 143 (1975).

65 See id. at $621-22,124$ Cal. Rptr. at I5I.

66 See Lyon v. Carey, 533 F.2d 649 (D.C. Cir. 1976).

67 See id. at $65 \mathrm{I}-52$.

${ }^{68} 398$ F.2d I67 (2d Cir. I968).

$69 \mathrm{Id}$. at $\mathrm{I} 72$.

70 The following passage from Judge Friendly's opinion supports the interpretation of the case as implicitly resting on notions of enterprise causation:

One can readily think of cases that fall on the other side of the line. If Lane [the sailor] had set fire to the bar where he had been imbibing or had caused an accident on the street while returning to the drydock, the Government would not be liable; the activities of the "enterprise" do not reach into areas where the servant does not create risks different from those attendant on the activities of the community in general. . . We agree with the district judge that if the seaman "upon returning to the drydock, recognized the Bushey security guard as his wife's lover and shot him," ... vicarious liability would not follow; the incident would have related to the seaman's domestic life, not to his seafaring activity, ... and it would have been the most unlikely happenstance that the confrontation with the paramour occurred on a drydock rather than at the traditional spot.

Id. (citations omitted). 
The other major class of intentional tort cases - in which the tort occurs at least in part because the agent seeks to further the interests of his principal - raises entirely familiar issues. In these cases, there is rarely any question that the existence of the agency "causes" the tort. ${ }^{71}$ Hence, subject to the previously discussed danger that vicarious liability may reduce the incentives of employees to avoid wrongful conduct or necessitate a spate of costly indemnity actions, the greater willingness of courts to impose vicarious liability in these $\operatorname{cases}^{72}$ is economically sound.

\section{Duty of a Master To Control Conduct of a Servant That Is Outside the Scope of Employment}

\section{Section 3 I 7 of the Restatement (Second) of Torts provides:}

A master is under a duty to exercise reasonable care so to control his servant while acting outside the scope of his employment as to prevent him from intentionally harming others or from so conducting himself as to create an unreasonable risk of bodily harm to them, if

(a) the servant

(i) is upon the premises in possession of the master or upon which the servant is privileged to enter only as his servant, or

(ii) is using a chattel of the master, and

(b) the master

(i) knows or has reason to know that he has the ability to control his servant, and

(ii) knows or should know of the necessity and opportunity for exercising such control. ${ }^{73}$

Under certain conditions, section 3 I 7 seemingly imposes vicarious liability on employers for tortious acts committed by employees that are not "caused" by the enterprise. Interestingly, however, vicarious liability will arise only if the employer is negligent - if he breaches his duty to exercise reasonable care. Thus, section 3 I 7 differs from conventional respondeat superior liability, which is strict. As noted earlier, strict vicarious liability is less efficient than vicarious liability based on negligence if the enterprise does not cause the tort. To this extent, if the scope of employment is circumscribed to encompass only

71 See Straiton v. Rosinsky, I83 Pa. Super. 545, I33 A.2d 257 (1957) (imposing vicarious liability on a theatre after an usher struck an unruly child with a flashlight); Howard v. Zaney Bar, 369 Pa. I55, 85 A.2d 401 (1952) (refusing to impose vicarious liability on a bar when a bartender shot a patron who harassed a female customer).

72 See, e.g., Straiton, I83 Pa. Super. at 547-48, I33 A.2d at 259; Prosser \& KeEton, supra note 20, at 505-06; W. SEAvey, supra note 49, at 157. But see Howard, $369 \mathrm{~Pa}$. 155, 85 A.2d 401.

73 Restatement (SECOND) OF TORTS $\$ 317$ (Ig65). 
those torts substantially "caused" by the business enterprise, section 3 I7's approach to torts committed outside the scope of employment is clearly efficient.

Section 3I7's requirement that the employer know or have reason to know that he has the ability, opportunity and need for control is also efficient. If the employer lacks such knowledge, vicarious liability imposes additional costs on the enterprise that lead to higher prices for enterprise goods and services without any attendant benefits to tort victims.

The requirement that the employee be on the employer's premises or be using the employer's chattels, however, is somewhat suspect. Perhaps one could argue that under such conditions the employer is more likely to be able to dissuade misconduct cheaply. Yet even if employees are on the employer's premises, close supervision of workers is sometimes quite costly; so too may be the supervision of an employee who uses a chattel at a considerable distance from the employer's premises. In addition, this requirement prevents the imposition of liability on the employer in some cases in which the employer can dissuade misconduct quite cheaply. To return to the example of the drunken sailor, an officer drinking at the same bar as an enlisted man may be able to dissuade the enlisted man's behavior quite easily. Yet, because the enlisted man is away from his boat and is not using his employer's chattel, the employer would escape liability under the $R e$ statement.

The application of section $3 I 7$ in practice, however, is much more limited than its language might suggest. Cases citing section $3 I 7$ or its earlier incarnation in the first Restatement, as well as the cases that the Restatement cites as the basis for section 3I7, primarily involve acts that would not have occurred absent the existence of the enterprise. Such cases do not raise issues of enterprise causation and might be better handled by treating the tort as within the scope of employment. ${ }^{74}$ Moreover, cases that rely on section $3 \mathrm{I} 7$ generally involve rather obvious acts of negligence on the part of the employer - for example, the knowing retention of an incompetent employee or the knowing allowance of dangerous practices by an employee even though relatively inexpensive measures could have stopped the practices. ${ }^{75}$

74 See, e.g., Fletcher v. Baltimore \& Potomac R.R., I68 U.S. 135 (I897) (finding that the employer knowingly allowed workers to throw firewood off moving trains); McCrink v. City of New York, 296 N.Y. 99, 7r N.E.2d 4I9 (1947) (holding that the city knowingly retained policeman with propensity for drunkenness who later shot two people while intoxicated on duty); Hogle v. H.H. Franklin Mfg. Co., I99 N.Y. 388, 92 N.E. 794 (I910) (finding that the employer allowed employees to throw objects out of a factory window). These cases are cited in the Reporter's notes to Section 317. See Restatement (SeCOND) of TORTS $\$ 317$ appendix, at 24 (1965); id. at 25-27 (listing court citations to the first Restatement).

${ }^{75}$ See, e.g., cases cited supra note 74 . 
One area that raises more difficult issues, however, is the growing line of cases imposing liability on employers for "negligent hiring." Typically, though not always, these cases involve intentional torts by employees with a history of criminal conduct or violent behavior that purportedly suggests unfitness for the job that they are employed to perform.

Vicarious liability may be efficient in these cases if the job subjects the tortfeasor to unusual stress or temptation or otherwise places him in circumstances that are especially conducive to repetition of past misbehavior. For example, it seems quite imprudent for a landlord to hire a convicted rapist as a security guard and give him a pass key to tenants' apartments. If a rape occurs as a result, the imposition of liability on the landlord is probably efficient, as the employment relationship seemingly facilitated ("caused") the tort. Even if the employer can do little to control the behavior of the guard after he is hired, liability will encourage the employer to perform a careful background check on applicants for such positions and to reject those applicants whose backgrounds are unsuitable. ${ }^{76}$

Vicarious liability is potentially inefficient, however, if the nature of the employment does not increase the likelihood of misbehavior, unless the employer has an opportunity cheaply and effectively to dissuade misconduct through monitoring or supervision. Cases that impose liability upon the employer for an assault by an employee against a co-worker or customer, principally because the employer had knowledge that the tortfeasor had committed assaults or other crimes in the past, ${ }^{77}$ are quite troubling. Absent a showing that the employer

${ }^{76}$ Few cases are so easy. Suppose, for example, that a background check of the applicant reveals that he once was discharged for sleeping on the job, that he had an arrest record for minor crimes, and that a female co-worker had once complained that he "made eyes at her." See Easley v. Apollo Detective Agency, 69 Ill. App. 3d 920, 926-27, 387 N.E.2d 1241, 124445 (1979) (reviewing a claim of attempted sexual assault by a security guard who used his pass key to gain access to the tenant's apartment). The employer in this case was held liable for compensatory damages under an Illinois statute that imposed liability on detective agencies for the misconduct of their employees. See Ill. Rev. STat., ch. 38, para. 20I-rob(10) (1975) (repealed 1984).

The employee's background would not have signaled to most employers that he might commit a rape. Nonetheless, security guards may face exceptional temptation and opportunity for malfeasance. The imposition of strict vicarious liability on employers of security guards who use their positions to facilitate criminal or tortious activity, as was accomplished by the Illinois statute in Easley, may then be justified because much of their malfeasance is arguably "caused" by their employment status.

77 See, e.g., Najera v. Southern Pac. Co., I9I Cal. App. 2d 634, 639 n.3, 13 Cal. Rptr. I46, I49 n.3 ( $196 \mathrm{I}$ ) (citing cases recognizing "the common law liability of employers for their direct negligence in hiring or retaining in their employ persons with known characteristics which might subject other persons to danger"); Tatham v. Wabash R.R., 412 Ill. 568, 107 N.E.2d 735 (1952) (holding that a complaint alleging that the employer knowingly employed a dangerous man to work with the plaintiff stated a cause of action in negligence under the Federal Employers' Liability Act). 
was in a position to intervene to prevent the assault and neglected to do so, the imposition of liability in these cases may simply cause the costs of production for the employer's enterprise to increase with no offsetting reduction in the incidence of wrongdoing. Alternatively, and much more probably, employers will choose not to hire individuals with a criminal record or other history of antisocial behavior. ${ }^{78}$ Society then loses the value of the labor services of such individuals, and their resulting inability to find gainful employment may well increase their propensity to commit wrongs. ${ }^{79}$

\section{Other ApPlications}

The economic principles developed above adapt readily to the study of the efficiency of vicarious liability in other areas. This Part

78 Arguably, if an employer has knowledge of an employee's violent propensities, he should at least have a duty to disclose those propensities to other employees to enable them to protect themselves. The difficulty with such a duty to disclose, however, is that disclosure may make it difficult or impossible for the individual who is the subject of the disclosure to work productively with fellow employees. As a consequence, prospective employers may simply decline to hire individuals with any history of violent behavior, with the adverse consequences discussed in the text.

${ }^{79} \mathrm{An}$ interesting and novel application of the "negligent hiring" doctrine is found in $\mathrm{Di}$ Cosala v. Kay, 9I N.J. 159, 450 A.2d 508 (1982). In that case, the employer - a Boy Scout camp - allegedly knew that its employee owned firearms and kept them in his living quarters on the grounds of the camp. During a social visit by the employee's nephew, his mother, and a 19-year-old camp counselor, the counselor found a loaded handgun and accidentally shot the employee's nephew. The New Jersey Supreme Court held that the plaintiff should have been allowed to reach the jury on the issue of negligent hiring or supervision.

The weakness of the causal relation between the injury and the employment relation in $D i$ Cosala is clear. The injury occurred during a social visit by the plaintiff to his uncle's house, a visit that could just as easily have taken place with the same unfortunate outcome in the absence of the employment relation.

In addition, the case differs dramatically from most negligent hiring cases in that no intentional misconduct by the employee was involved (the employee was not even present at the time of the accident), and no question was raised about the employee's character or fitness for his position. Rather, the plaintiff's theory was simply that the employer had knowledge that the firearms were present and should have refused to allow them to be kept in living quarters that the employer had supplied to the employee on the grounds of the camp.

Despite the rather unusual circumstances of this case, vicarious liability is at least arguably efficient. Given the propensity of children to play with firearms, and the serious danger of resulting accidents, it is perhaps negligent to store them at all at a Scout camp, at least without special precautions. Although the principal danger created by such negligence is that of injury to a camper, the possibility of injury to a social guest also plainly exists. An employer with actual knowledge that the firearms are in the possession of an employee under these conditions can insist that they be removed from the camp or be safely stored. The implementation of such a policy probably costs the employer very little (simply the effort of issuing a verbal command), and employees ordinarily can be expected to abide by the policy. The case thus seemingly presents an instance in which, despite the weakness of the causal relation between the tort and the employment relation, vicarious liability is justified because the employer has an opportunity to dissuade misconduct cheaply and effectively through supervision. 
explores the vicarious liability of motor vehicle owners who lend their cars to third parties who cause injury, of premises owners whose guests or tenants suffer torts committed by intruders, and of employers whose employees are sexually harassed by their supervisors or coworkers. These topics introduce new twists to the analysis, such as the significance of contractual relationships between the party to be charged with vicarious liability and the injured party (in the premises liability and sexual harassment cases). Like the cases analyzed in Section II, these cases also raise interesting questions about causation.

\section{A. The Vicarious Liability of Motor Vehicle Owners}

A motor vehicle owner's liability for torts committed by a driver who borrows the owner's vehicle varies considerably among jurisdictions. ${ }^{80}$ In some states, the owner only incurs liability for a tort committed by the other driver when the owner himself committed some act of negligence, such as entrusting the vehicle to a driver known to be incompetent, or allowing a driver to drive recklessly while the owner is riding as a passenger. ${ }^{81}$ The modern trend, however, is toward an expansion of owners' liability for the negligence of other drivers, with an increasing prevalence of strict vicarious liability in many jurisdictions. Some states permit plaintiffs to argue that an owner who rides as a passenger retains a right of control over the driver that creates a "master-servant relationship," thereby subjecting the owner to liability under a theory of respondeat superior. ${ }^{82}$ One state imposes strict liability on the theory that because the automobile is a "dangerous instrumentality," the owner incurs liability for the negligence of anyone to whom he entrusts it. 83 Another basis for strict vicarious liability is the "family purpose doctrine," under which family members are deemed "agents" of the owner when using the automobile for a "family purpose." 84 Finally, about a dozen states have imposed strict vicarious liability through "automobile consent" statutes. ${ }^{85}$ These statutes generally hold automobile owners liable for the negligence of anyone who uses the automobile with the owner's express or implied permission.

As with any form of vicarious liability, imposing liability on automobile owners would have no economic consequences if the drivers could always pay judgments against them in full (with or without the aid of insurance) and if drivers and owners could costlessly negotiate

${ }^{80}$ For a reasonably complete survey of motor vehicle owners' liability across jurisdictions, see Prosser \& KeEton, cited in note 20 above, $\S 73$, at 522-28.

81 See id. at 523.

82 See id.

83 See id. at 524.

${ }^{84}$ See id.

85 See id. at 527 . 
between themselves to allocate the risk of civil liability. The ultimate incidence of liability would then be determined by agreement between drivers and owners, without regard to who bears liability under the law.

Plainly, however, many drivers are incapable of paying judgments against them, and customized risk-allocation agreements between owners and drivers are rarely negotiated because they are costly. The imposition of vicarious liability on the owners of automobiles thus raises a number of issues closely related to the issues that arose in the earlier analysis of the frolic and detour cases, such as the extent of causation and the cost and effectiveness of incentive devices.

If someone borrows a motor vehicle for personal use and commits a tort, no obvious relationship to any business enterprise is present - a fact that might seem to distinguish the frolic and detour cases. Even so, the concept of enterprise causation remains relevant. For example, suppose that a tort occurs when a parent sends his child on an errand for the parent. The tort is then "caused" by the parent's activities, and the risk of the tort should be taken into account by the parent in deciding whether to undertake the activity himself or to send his child to undertake it. The parent's calculus in this respect is analogous to that of a business, which takes into account the costs attendant upon its operation in determining the scale at which to operate.

Alternatively, suppose that the parent lends an automobile to a child so that the child can run a personal errand of his own. In that capacity, the parent functions much like an auto rental agency, except that the child likely does not pay for the use of the vehicle - the parent's returns are psychic rather than monetary. Just the same, the costs of the tort are "caused" by the family "business" that provides the child with an automobile for personal use. Those costs should be taken into account in determining the scale at which to operate that "business" - the number of vehicles to purchase and the extent to which children may use them - and in designing incentives within the family to encourage the child to drive carefully when parents grant permission to use a vehicle.

With these observations in mind, consider now the alternative approaches of various jurisdictions to the liability of motor vehicle owners for torts committed by a driver who borrows the vehicle.

I. Negligence. - Not surprisingly, all jurisdictions provide a right of action against negligent automobile owners, even if the driver is also negligent. Beyond question, such a right of action is efficient. Whether the owner entrusts an automobile to an incompetent driver, provides a driver with a negligently maintained vehicle, or fails to exercise opportunities to dissuade negligent driving while riding as a passenger, the imposition of liability is appropriate to deter owners from such careless behavior. Of course, the driver must also be liable 
for his own negligence, and it may often be efficient for owners to have a right to indemnity from the negligent driver who causes the tort. 86

Some jurisdictions, however, limit the right of action against the owner to circumstances in which the owner has been negligent. This policy is suspect. When drivers are judgment-proof, a variety of inefficiencies arise if the drivers alone are liable for their torts. Their inability to pay judgments may reduce their incentive to drive with care and lead them to undertake activities that require driving even if the (partially externalized) costs of those activities exceed their benefits. In addition, insolvent drivers may have little incentive to purchase liability insurance because a successful plaintiff cannot collect from them, and the efficiency of risk-sharing will suffer.

2. Variations of Strict Vicarious Liability. - Strict vicarious liability can mitigate the inefficiencies that arise if the owner is held liable only when negligent. First, it motivates the owner of the vehicle to employ certain worthwhile incentive devices that might encourage the driver to exercise care and that might not be required by the due care standard in a negligence regime. Parents, for example, can condition the continued use of the family automobile by a child upon the avoidance of accidents. Moreover, as suggested in the analysis of the frolic and detour cases, any moral hazard attendant upon shifting liability from the driver to the owner is likely to be modest even if the owner does not pursue indemnity or employ some other incentive device to motivate the driver. As noted earlier, the widespread prevalence of liability insurance for automobile accidents (usually with risk-related insurance premiums) suggests that the moral hazard problem is not unmanageable. Second, the imposition of liability upon the owner may encourage him to deny use of the automobile when the activity of driving is not worth the risk. If the owner is a rental agency, for example, the efficient level of driving activity will result when the agency charges a rental rate that covers its expected costs of operation, including its expected liability. If the owner is a parent, the efficient level of driving activity will result when the parent limits each child's driving to occasions of sufficient importance to justify the risk. Third, the imposition of liability on the owner will encourage the purchase of liability insurance, especially if other drivers are unable to pay judgments themselves. Risk will then be shifted to an efficient risk bearer.

This analysis lends support to the "family purpose doctrine." The most common application of that doctrine - the imposition of liability

86 See Landes \& Posner, supra note 1 , at $527-28$ (arguing that $B$ should have a right of indemnity against $A$ any time either one acting alone could have avoided an accident but $A$ could have done so more cheaply than $B$ ). 
on parents for torts by their children - arises in situations in which the tortfeasor is generally quite impecunious.

By contrast, the limitation of strict vicarious liability in some jurisdictions to circumstances in which the owner is present as a passenger is more difficult to justify. Vicarious liability in such cases may well be efficient: the presence of the owner in the vehicle may provide the owner with an opportunity to dissuade the driver from negligence, and the occurrence of a tort might indicate that the owner has negligently failed to do so. Alternatively, perhaps the presence of the owner suggests that the activity of driving is necessitated by the owner's personal business, and this causal relation to the owner's personal activities warrants vicarious liability just as a causal relation to an employer's business enterprise often warrants vicarious liability in the frolic and detour cases. Nevertheless, the limitation of vicarious liability to circumstances in which the owner is present seems illadvised. Such a limitation will bar liability in some instances in which the economic case for vicarious liability is strong, as when a parent lends an automobile to an impecunious child.

Finally, the consent statutes, the broadest extension of strict vicarious liability, are arguably efficient. To be sure, these statutes increase the transaction costs of the tort system by adding additional parties to litigation even in cases in which vicarious liability provides few benefits. Yet if an important benefit of vicarious liability is improvement in the efficiency of risk-sharing, other transaction costs may be reduced by the approach of the consent statutes, which allow plaintiffs to reach the insurance coverage on the injurer's vehicle without regard to the insurance coverage of the injurer himself - if the state wishes to ensure a minimum level of insurance coverage to compensate the injured party in any accident, enforcing compliance with respect to each registered vehicle may be cheaper than enforcing compliance by each driver, because the number of drivers considerably exceeds the number of vehicles. Transaction costs may also be reduced by the existence of a bright-line rule of vicarious liability that avoids the need for litigation over the circumstances in which vicarious liability provides clear economic benefits. Such efficiencies may indeed justify the approach of the consent statutes.

\section{B. The Vicarious Liability of Premises Owners for Torts by Intruders}

Increasingly, premises owners incur vicarious liability for intentional torts (usually criminal acts) commited by intruders. ${ }^{87}$ Landlords

${ }^{87}$ See generally Brown \& Doyle, Growing Liability for Premises Owners, A.B.A..J., Mar. I, I986, at 64 . 
may incur liability for torts against tenants 88 and innkeepers may incur liability for torts against guests. ${ }^{89}$ The liability of premises owners in these cases usually rests on a negligence theory, a claim that the premises owner failed to provide adequate security against intruders. ${ }^{90}$ Courts that accept this theory typically hold that the premises owner owes a duty to take reasonable precautions against a foreseeable risk of crime. ${ }^{91}$ To my knowledge, no court has gone beyond the negligence approach to impose strict vicarious liability on premises owners for intentional torts committed by intruders.

These cases differ from the cases previously analyzed because of the existence of a contractual relationship between the injured party and the premises owner. The intruder cases also raise a number of interesting economic questions about the "cause" of the tortious activity at issue, as well as the social utility of security measures.

Suppose, for example, that a motel chain builds a motel in the midst of a business district with a low and stable crime rate. Suppose further that the motel cannot take precautions to reduce the incidence of crime against guests of the motel. After the motel is built, all variables that affect the crime rate remain constant, and the crime rate remains unchanged from the period before the motel was constructed. Nonetheless, a few guests of the motel are victimized by criminal activity for which a remedy lies in tort.

Under the assumed conditions, the motel is plainly not the "cause" of any crime or tort. The construction of the motel has not affected the incidence of crime, and it is merely happenstance that guests of the motel are occasionally victimized - if the motel did not exist, criminals would simply locate other victims. The costs of crimes against guests, therefore, are not attributable to the motel and, given that the motel cannot take precautions, it would be inefficient to require the motel to bear tort liability for crimes against guests. This is true for the same reasons that it is generally inefficient to hold employers liable for torts by employees that are not "caused" by the employment relationship or whose probability the employer cannot reduce through incentive devices. Even if the guests' willingness-to-

${ }^{88}$ See, e.g., Kline v. I500 Mass. Ave. Apartment Corp., 439 F.2d 477 (D.C. Cir. 1970); Pippin v. Chicago Hous. Auth., 78 Ill. 2d 204, 399 N.E.2d 596 (1979). See generally Annotation, Landlord's Obligation to Protect Tenant Against Criminal Activities of Third Persons, 43 A.L.R.3D 33I (I972).

${ }^{89}$ See, e.g., Garzilli v. Howard Johnson's Motor Lodges, Inc., 419 F. Supp. 12 10 (E.D.N.Y. 1976); Gray v. Kircher, 193 Cal. App. 3d 1069, 236 Cal. Rptr. 891, 892-93 (1987). See generally Annotation, Liability of Hotel or Motel Operator for Injury to Guest Resulting from Assaull by Third Party, 28 A.L.R.4TH 80 (1984).

90 See Prosser \& KeEton, supra note 20, at 442-43.

91 See id. ("A growing number of courts have imposed ... duties of reasonable protection upon landlords to protect their tenants, and to protect others perhaps as well, from criminal attack, provided that such assaults are reasonably foreseeable and preventable."). 
pay rose by the value of the "insurance" provided by the motel chain, vicarious liability would still be inefficient because it would foster unnecessary litigation.

Now suppose that the motel can reduce the incidence of crimes against guests through investment in additional security measures: dead-bolt locks, patroling watchmen, and the like. Assume further that the costs of these security measures are less than the associated reduction in the expected costs of crimes against guests. Hence, motel guests collectively would be willing to pay the motel operator an amount in excess of the cost of the security measures. In a world of perfect information, the operator would undertake such measures voluntarily, knowing that he could raise room rates to recoup the cost without losing customers. Yet guests may not possess the information necessary to factor the quality of security into their willingness-to-pay for a room, and thus a market solution may not materialize.

Nonetheless, the law should not necessarily impose a duty on the proprietor to undertake the security measures. The private value of security measures (as between the motel and its guests) may considerably exceed their social value. If security measures do not reduce the incidence of crime but merely redirect criminals to easier targets, then the added safety of motel guests is offset by reduced safety for others in the neighborhood. In this case, the optimal contract from the perspective of the motel and its guests is not socially optimal, and the security measures are inefficient from a societal perspective. On the other hand, if security measures deter crime altogether, their private and social value will converge. The imposition of a duty upon motel operators to undertake cost-effective security measures may then be efficient. ${ }^{92}$

For yet another variation in the analysis, suppose that a motel is constructed in a dangerous neighborhood, making its guests natural targets for crime and increasing the crime rate. An argument could then be made for strict vicarious liability on the theory that the motel "caused" the wrongs against its guests; if guests are poorly informed about security so that no market penalty is exacted for the dangerous location, the imposition of vicarious liability for crimes that are caused by the decision to locate in a dangerous neighborhood will help to provide efficient locational incentives and to discourage the construction of motels where the resulting crimes against guests may impose a cost that exceeds the surplus from the services of the motel. To be sure, some sort of contributory negligence defense would still be nec-

92 Such a duty may be inefficient, however, for another reason. If the market fails to provide adequate security measures because of poor consumer information, the adoption of legally mandated security measures may not increase consumer willingness-to-pay. The result may be a decline in consumption of motel services with a resultant loss of economic surplus that may partially offset the benefits of the security measures. 
essary to ensure that guests take precautions themselves (such as locking their rooms). ${ }^{93}$

In sum, if the existence of the motel creates a special temptation for criminals or otherwise leads to an increase in the total number of crimes, then strict vicarious liability might be efficient; otherwise, motel operators should incur liability only for failure to utilize costeffective security measures. This principle raises the question what measures are "cost effective" and highlights the possible distinction between the private and social value of security measures. If security measures have no social value, then a duty to undertake them is inefficient a fortiori.

As noted earlier, modern case law on premises liability for the intentional torts of intruders, whether applied to motel operators, apartment landlords, or other premises owners (except private homeowners), applies a negligence standard. It imposes a duty on the premises owner to take reasonable security measures against foreseeable risks of crime or tort but stops short of strict liability. This approach is efficient if $(\mathrm{x})$ premises owners do not "cause" intentional torts by intruders to a substantial degree; (2) premises owners can nonetheless deter such torts through cost-effective security measures that protect persons on their premises without simply redirecting the tortfeasor to an easier mark; and (3) because of information costs or other transaction costs, the efficient use of security measures will not result by contract.

The first two assumptions are at least plausible in most premises liability cases and, as suggested above, the third is also plausible with respect to cases involving innkeepers. The third assumption is far less plausible, however, for another important class of premises liability cases - suits by tenants against their landlords.

The leading case of Kline v. I500 Massachusetts Ave. Apartment Corp. ${ }^{94}$ is illustrative. A tenant was assaulted and robbed in a common hallway, presumably (though not certainly) by an intruder. The victim had been a tenant in the building for approximately seven years prior to the assault. During that time, a number of security measures in the building had been discontinued - the desk attendant in the lobby was no longer present on a regular basis, the building no longer had a doorman, an entrance to the garage was no longer guarded regularly, and the rear entrance was no longer kept locked at all times. The D.C. Circuit, in a 2-I decision, held that the

93 Note that vicarious liability probably would not have much effect on the incentives of criminals to commit crimes - the motel would have a right to indemnity against any criminal with significant financial assets, and criminal penalties would still apply to all criminals who were apprehended.

${ }^{94} 439$ F.2d 477 (D.C. Cir. I970). 
defendant-landlord had breached his duty of reasonable care to protect tenants from assaults by third parties.

Specifically, the majority concluded that a duty to provide security for the entrances and common areas of the building should be imposed on the landlord because the landlord had exclusive control over them and because he had reason to anticipate that assaults would occur without adequate security. To satisfy that duty, the court held that the landlord was obliged to maintain the "same relative degree of security" that was in effect at the time the plaintiff became a tenant in the building, because she "was led to expect that she could rely upon this degree of protection." 95

The dissent, among other things, suggested in effect that the court should not second-guess the market. 96 Its argument was simple tenants can select a building and a neighborhood according to their willingness-to-pay for security, location, and other amenities. The dissent argued that the court imprudently substituted its judgment about the appropriate level of security for the collective judgment of the landlord and the tenants as reflected in their leases and in the level of security customarily provided by the landlord. ${ }^{97}$ Such a substitution was especially inappropriate, the dissent maintained, when the tenant of seven years was well-informed about the level of security. ${ }^{98}$

Upon reflection, the argument of the dissent is compelling. As noted above, the plausible rationale for the imposition of negligencebased vicarious liability on innkeepers includes an assumption that their guests are imperfectly informed about the dangers of the neighborhood and the need for security, and perhaps the quality of the security that innkeepers offer. As a consequence, customers may place insufficient value on security, and their willingness to pay may not compensate the innkeeper for instituting efficient security measures. The incentive to provide them is then lost.

Because the landlord-tenant relation typically extends over a much longer period of time than the innkeeper-customer relation, however, tenants can develop information about the need for security in the neighborhood. Moreover, because most tenants anticipate a stay of some months or years, it pays for them to invest in the acquisition of information about the safety of a neighborhood before moving into it. They are then in a position to assess the value of security measures in their rental alternatives. Landlords recognize this behavior of tenants and have every incentive to provide security services for which

95 Id. at 486.

${ }^{96}$ See id. at 492-93 (MacKinnon, J., dissenting).

97 See id. at 492.

98 See id. 
prospective tenants are willing to pay through higher rents ${ }^{99}$ - by definition, all efficient security measures. ${ }^{100}$

Thus, the trend in the case law toward expanded landlord liability for assaults by intruders is disquieting. ${ }^{101}$ Whatever the merits of innkeeper liability, the liability of landlords is perhaps best left to the realm of contract.102 This conclusion is reinforced by the observation above that the private value of security measures may exceed their social value, so that even the security measures required by contract may be economically excessive. Under these circumstances, it seems

99 A possible objection to this analysis is that landlords can reduce the quality of security in a rental building, up to a point, without inducing existing tenants to leave. Moving is costly, and tenants will not move out until the cost imposed upon them by a decline in security exceeds the cost of finding and moving into another apartment. Thus, it might be argued, landlords can entice tenants to a building by providing the efficient level of security initially and then reduce the level of security later without penalty.

This argument presupposes, however, that natural turnover in rental units is low. Setting aside the complications of rent control, see infra note 103, most landlords must continually fill vacancies by attracting new tenants. Even if existing tenants are perhaps unlikely to move out solely in response to a decline in security, the fact that the landlord must fill vacancies that arise for other reasons provides him with a strong incentive to offer and to maintain adequate security measures. Cf. Schwartz \& Wilde, Intervening in Markets on the Basis of Imperfect Information: A Legal and Economic Analysis, 127 U. PA. L. REv. 630 (1979) (arguing that a relatively low percentage of consumers who comparison shop actively can generate efficient competitive equilibria). There can be no assurance that this process will operate perfectly in all cases, but neither can a case be made for systematic judicial intervention, especially in light of the possibility that the level of security that emerges by contract may be economically excessive due to a divergence of the private and social values of security measures.

100 The analysis of the majority in no way undermines this proposition. To be sure, if security measures are to be instituted at all with respect to building entrances and common areas, the landlord must put them in place. Even if such measures are in the interests of the tenants collectively, no single tenant will purchase them on his own, and collective action to purchase them is probably too costly. Yet as the analysis in the text suggests, landlords do have an incentive to supply security measures that cost less than their value to the tenants (measures that are cost effective from the tenants' perspective) because they can then raise rents by more than enough to compensate.

As for the suggestion that the plaintiff was led to rely on the security measures in place six years before the assault, the response of the dissent is a proper one: the decline in security over time was obvious to the plaintiff, yet she continually renewed her month-to-month tenancy. It is thus incorrect to suggest, as the majority opinion implied, that the decline in security was somehow a breach of an implicit contractual obligation.

101 See, e.g., Samson v. Saginaw Professional Bldg., 393 Mich. 393, 224 N.W.2d 843 (1975) (imposing a duty of care on a landlord for an assault by a mental patient of a tenant upon the employee of another tenant); Johnston v. Harris, 387 Mich. 569, I98 N.W.2d 409 (1972) (holding that a landlord may be negligent in creating conditions conducive to third-party criminal activities); see also Frances T. v. Village Green Owners Ass'n, 42 Cal. 3d 490, 723 P.2d 573, 229 Cal. Rptr. 456 ( 1986 ) (en banc) (holding that a condominium association may be liable for an assault by an intruder upon a unit owner).

102 The role of tort, if any, should be limited to the redress of breaches of "implied contract." For example, Kline would be a different case if the assault had resulted from a sudden and unanticipated discontinuation of security services that the landlord had expressly or impliedly agreed to provide (such as the failure of the doorman to show up for his shift). 
especially ill-advised to impose upon landlords a duty to take greater precautions against intruders than their contractual obligations require. ${ }^{103}$

\section{The Vicarious Liability of Employers for Acts of Sexual} Harassment by Employees Against Subordinates or Co-workers

r. Legal Background. - Sexual harassment in the workplace may constitute a common law intentional tort. Depending upon the nature of the harassment and the jurisdiction, an action may lie for intentional infliction of emotional distress, wrongful discharge, assault, battery, invasion of privacy, or interference with contract. ${ }^{104}$ In any such tort action, the plaintiff may seek a judgment against the employer of the offending individual. Common law tests for vicarious liability will then apply; the plaintiff must normally demonstrate that the offending individual was a "servant" and that the tort occurred within the scope of his employment.

Some acts of sexual harassment also constitute discrimination on the basis of sex in violation of title VII of the Civil Rights Act of I964. ${ }^{105}$ Thus, instead of a common law tort action, or perhaps in addition to one, some victims of sexual harassment may file a complaint with the Equal Employment Opportunity Commission (EEOC). If the EEOC fails to resolve the complaint satisfactorily through conciliation within a specified period, the complainant may bring an action in federal court. 106 In practice, the backlog of cases at the EEOC virtually ensures that the conciliation period will elapse before the complaint is resolved, and hence most complainants ultimately

103 This process breaks down in the presence of rent control, which may prevent landlords from raising the rent to capture the greater willingness-to-pay that results from improved security and may greatly reduce the natural turnover in rental units that forces landlords to maintain security in order to attract new tenants. See supra note 99 . Indeed, one of my students, who lived in northwest Washington, D.C. at the time of the Kline decision, conjectures that the deterioration of security measures at I500 Massachusetts Ave. may well have followed the imposition of rent control. I have been unable to confirm or refute this hypothesis.

104 See, e.g., Monge v. Superior Court ex rel. Crown Gibraltar, 176 Cal. App. 3d 503, 508, 222 Cal. Rptr. 64, 66 (rg86) (recognizing causes of action for intentional infliction of emotional distress, wrongful termination of employment, and breach of implied covenant of good faith and fair dealing between employer and employee); Drinkwalter v. Shipton Supply Co., 732 P.2d 1335, 1338 (Mont. 1987) (holding that sexual harassment may constitute a breach of the employment contract's covenant of good faith and fair dealing and may also give rise to actions for wrongful discharge on public policy grounds).

105 The Supreme Court held that sexual harassment can violate a person's civil rights under title VII in Meritor Sav. Bank v. Vinson, I06 S. Ct. 2399 (1986). The Court based its holding on 42 U.S.C. $\$ 2000 \mathrm{e}-2(\mathrm{a})(\mathrm{I})$ (1982), which prohibits employers from discriminating "against any individual with respect to his compensation, terms, conditions, or privileges of employment, because of such individual's ... sex."

106 See generally B. Schlei \& P. Grossman, Employment Discrimination Law $42 \mathrm{I}-29$ (2d ed. 1983). 
have the option to bring suit. The remedies for a successful action include lost pay and injunctive relief but do not include certain compensatory damages ${ }^{107}$ (such as damages for emotional distress) or punitive damages.

Victims must sue the "employer," which is defined to include agents of the employer. ${ }^{108}$ Thus, a critical issue in sexual harassment cases under title VII, as in cases brought in tort, is the existence of an agency that would establish employer liability. Indeed, under title VII, employer liability is an absolute prerequisite to suit.

The Supreme Court addressed the standards for employer liability in sexual harassment suits under title VII in Meritor Savings Bank v. Vinson. ${ }^{109}$ In Meritor, the Court distinguished three types of sexual harassment: (a) "quid pro quo" harassment, whereby supervisory personnel seek sexual favors in return for promotions, raises, and the like; (b) "hostile environment" harassment by supervisory personnel, whereby a supervisor seeks sexual favors from a subordinate without expressly offering any quid pro quo (the situation in Meritor) and does so with sufficient frequency or offensiveness that the harassment becomes actionable under title VII; and (c) hostile-environment harassment by co-workers, without participation by supervisory personnel. 110

The Court suggested that a rule of strict vicarious liability will generally apply to quid pro quo harassment by supervisory personnel. Such a rule had already been adopted by a number of courts and was set forth in the EEOC guidelines on sexual harassment. ${ }^{111}$ As to hostile-environment harassment by supervisory personnel, the Court declined to set forth a standard for employer liability and instead suggested that the issue should be resolved case by case through the application of common law agency principles. ${ }^{112}$ By implication, common law agency principles will also guide cases of hostile-environment

107 See id. at $\mathbf{1} 452$.

${ }^{108}$ See 42 U.S.C. $\$ 2000 e(b)$ (1982). Although the law on this point is sketchy, it appears that the liability of co-defendants (for example, the company and its offending "agent") is joint and that the court may apportion damages between them as it sees fit. See, e.g., Russell v. American Tobacco Co., 528 F.2d 357 (4th Cir. 1975) (holding the union and employer jointly liable), cert. denied, 425 U.S. 935 (1976). An unsuccessful defendant has no right to contribution (or, presumably, indemnity) against a party who might have been joined as a defendant in the original action but was not. See Northwest Airlines, Inc. v. Transport Workers Union, 45 I U.S. 77 (198I). At the time of the original action, however, defendants can seek to join other parties as co-defendants and assert cross-claims against them. See B. Schlei \& P. Grossman, supra note 106, at 647-5 I.

109 106 S. Ct. 2399 (1986).

110 See id. at $2405-08$.

111 See id. at 2407-08 (citing Brief for United States and Equal Employment Opportunity Commission as Amicus Curiae at 22, 26, Meritor (No. 84-1979)); 29 CFR § 1604.II(c) (1985).

112 See Meritor, $106 \mathrm{~S}$. Ct. at 2408. 
harassment by nonsupervisory personnel, although Meritor was not directly concerned with such harassment.

Finally, the Court's analysis made clear that the employer's liability may be predicated on his negligence. Negligence may exist if the employer fails to adopt a policy against sexual harassment and to provide an effective grievance procedure for victims of harassment or has actual knowledge of harassment and fails to take remedial action. ${ }^{113}$ Lower courts had previously adopted a rule of liability based on the employer's negligence that typically required actual or constructive knowledge of harassment on the part of the employer in addition to a failure to take remedial action. ${ }^{114}$

In a concurring opinion, Justice Marshall argued that the application of agency principles to hostile-environment harassment by supervisory personnel should almost always lead to a finding of agency and thus to employer liability. ${ }^{115}$ Justice Marshall reasoned that harassment by a supervisor is facilitated by the supervisor's position in the company hierarchy, whether or not a quid pro quo is offered. $\mathrm{He}$ therefore found no justification for a different standard of employer liability in these two types of cases.

2. Economic Analysis. - The efficiency of vicarious liability in sexual harassment cases involves the same economic issues as the efficiency of vicarious liability in intentional tort cases. What distinguishes the harassment cases from many cases involving intentional torts by employees, however, is the existence once again of a contractual relationship between the injured party and the employer of the wrongdoer.

The significance of this contractual relationship is unclear. If potential targets of harassment are fully informed of the risk of harassment prior to accepting employment, employers must compensate workers subject to a greater risk of harassment with higher wages. Employers then have an incentive to adopt workplace policies that reduce the costs of harassment and will do so to the point at which the reduction in those costs (as measured by the decline in wages of prospective targets of harassment) is at the margin equal to the costs of further antiharassment measures. In addition, to the extent that some harassment remains after the adoption of all cost-effective measures against it, victims of harassment will be compensated by higher wages, and the costs of workplace harassment will be borne by the employer through the wage bill.

Yet the underlying premise of this analysis may be incorrect. In practice, prospective employees may have little information about the

113 See id. at 2408-09.

114 See, e.g., Tomkins v. Public Serv. Elec. \& Gas Co., 568 F.2d 1044, 1048-49 (3d Cir. 1977).

115 See Meritor, 106 S. Ct. at 2409-I I (Marshall, J., concurring). 
probability and seriousness of workplace harassment prior to accepting employment. Of course, once the costs of harassment become apparent, a victim of harassment can always quit and find a different job, but the costs of doing so (search costs, forfeit of returns to nontransferable investments in training, and so on) may outweigh the benefits. Even if the victim does quit, significant injury to the victim already may have occurred, and the employer may simply hire another illinformed employee at the same wage rate. Hence, it is doubtful that a market solution to the problem of sexual harassment will emerge systematically. ${ }^{116}$

If a market solution does not materialize, employers will not bear the costs of harassment "caused" by their business enterprise or adopt cost-effective policies to discourage harassment, absent the imposition of civil liability. The analysis can then proceed as if acts of harassment are committed against strangers rather than against individuals who have a contractual relationship to the employer. In this case, the principles developed in Part I apply directly. ${ }^{117}$ If the harassment is "caused" by the employer's enterprise, this fact weighs in favor of strict vicarious liability. Liability based on negligence is more efficient if the causal relation between the enterprise and the harassment is weak but the employer can nonetheless adopt inexpensive, effective incentive devices to dissuade employees from misconduct. Consider now the various forms of sexual harassment and their legal treatment after Meritor.

(a) Sexual Harassment by Supervisory Employees. - A strong argument can be made that harassment by supervisory employees is "caused" by the employer's enterprise, whether or not a quid pro quo is part of the harassment. To be sure, some supervisory employees would commit acts of harassment irrespective of their position but, as Justice Marshall suggested in Meritor, sexual harassment by supervisors is often facilitated by a position of authority. ${ }^{118}$ Absent the

116 Contrast this analysis to the analysis of landlord liability for intruders in Kline. See supra pp. 600-03. The difference there lies in the ability of prospective tenants to obtain information about the safety of the neighborhood and to observe the quality of security measures before they move into a rental building. Landlords then have an incentive to provide the security measures that tenants collectively regard as cost effective, with the expectation that the cost can be recouped through higher rents. Concomitantly, a failure to provide cost-effective security measures will lower the willingness-to-pay of prospective tenants by an amount that exceeds the cost savings to the landlord. A "market solution" to the problem of sexual harassment is much less likely to emerge, because prospective employees will often have little or no information about the risks of sexual harassment before they accept a new position.

117 Moreover, in any cases in which information problems are overcome and the market solution does materialize, nothing is lost, save perhaps the transaction costs of litigation, by applying the same standard of employer liability to those cases as is applied in other cases an implication of the Coase Theorem. See Coase, supra note ro.

118 See Meritor, Io6 S. Ct. at 2410-I I (Marshall, J., concurring). 
existence of a supervisor-subordinate relationship, the supervisor would have no leverage over the subordinate, and the likelihood of sexual harassment would be significantly reduced. Of course, the causal relation to the enterprise is strongest in quid pro quo cases, because such harassment cannot occur absent the enterprise hierarchy. Therefore, the case for strict vicarious liability is strongest for quid pro quo harassment but may also be quite strong for hostile-environment harassment by supervisory personnel.

A possible objection to strict vicarious liability is that it might lead to increased harassment by reducing the incentive for supervisory employees to behave responsibly. This objection seems unfounded. To be sure, employers probably cannot observe acts of harassment very frequently and thus cannot intervene to prevent it. But they can (and do) promulgate policies under which employees who commit acts of harassment are discharged or otherwise penalized with regard to advancement, salary increases, and the like. Such incentives are potentially effective for all employees who value long-term relationships with their employers. ${ }^{119}$

Another possible objection to strict vicarious liability for sexual harassment by supervisors is that it may lead to meritless lawsuits. When an employee is fired, for example, the employee may be tempted to fabricate a sexual harassment claim to save face. Arguably, this is a serious problem, because sexual harassment suits often turn solely on an assessment of the credibility of the witnesses. As a result, the chances of success in a meritless lawsuit may be significant.

Yet it is important not to exaggerate this concern. Just as the difficulties of proof may enhance the chances of success and settlement value of meritless suits, they also reduce the chances of success in meritorious suits, especially given that the plaintiff bears the burden of proof. Moreover, victims of sexual harassment may be reluctant to file suit or even to report incidents to their employers for fear of reprisal or a tainted reputation in the labor market. In sum, whatever incentives exist for meritless suits are substantially counterbalanced by incentives against meritorious suits, which will reduce the aggregate costs to employers of sexual harassment suits to a level that may well fall below the true costs of harassment in the workplace.

Thus, assuming that some combination of incentives will enable the employer to reduce the incidence of sexual harassment (or at least to avoid a significant increase in harassment), and assuming that the problem of meritless suits is not a terribly serious one, a strong argument can be made for strict vicarious liability for acts of harassment

119 Indemnity actions may provide yet another disincentive to harassment, albeit a highly imperfect one. Indemnity is apparently not available under title VII. See Anderson v. Local Union No. 3, 582 F. Supp. 627,633 (S.D.N.Y. 1984). At present, the development of an indemnity action would be a useful addition to the incentive devices available to the employer. 
against subordinates by supervisory employees. The causal relation between such acts and the employer's enterprise is probably quite strong, and the market is unlikely to produce an efficient solution to the problem of sexual harassment in many cases, notwithstanding the contractual relationship between the employer and the injured party.

(b) Sexual Harassment by Nonsupervisory Co-Workers. - The causal relation to the enterprise is clearly weaker in cases of harassment by nonsupervisory co-workers. These co-workers have no leverage to exert over the individual who is the object of harassment, and individuals prone to commit acts of harassment in the absence of any leverage may well do so irrespective of their occupation, position, employment, or unemployment. Hence, the probability that they will engage in harassment may be unaffected, or affected only slightly, by their employment relationship. Strict vicarious liability for such harassment will almost certainly be inefficient. Vicarious liability based on negligence may be efficient, however, if employers are capable of significantly reducing the incidence of sexual harassment through inexpensive incentive devices.

Interestingly, as noted earlier, the rule of employer liability applied by most courts in these cases requires actual or constructive knowledge of harassment on the part of the employer, coupled with a failure by the employer to take remedial action. ${ }^{120}$ This rule may well be efficient if one supposes that the employer cannot cost effectively diminish sexual harassment except by announcing a policy against it and taking disciplinary action under that policy after receiving knowledge of specific incidents of harassment - a highly plausible assumption.

Thus, more or less consistent with existing law, perhaps the best rule for cases involving harassment by nonsupervisory co-workers is to impose a duty on employers to announce policies against sexual harassment and to provide channels through which victims of harassment can complain to the employer. Once such a policy is in place, the failure of an employee to report harassment to the employer should act as a bar to vicarious liability unless the employer can be shown to have knowledge of the harassment through other channels. The employer should also escape liability if, despite a report of harassment, the employer makes a good faith judgment that the report lacks credibility or is unable to remedy the problem despite reasonable efforts to do so.

\section{CONCLUSION}

This Article has extended the previous economic treatment of vicarious liability, which focused on risk-sharing, cost internalization, 
and incentive maintenance in the employment relationship as the key economic issues, to incorporate probabilistic notions of causation. The scope of employment limitation upon respondeat superior liability may be understood in many instances as a way to limit the employer's liability to torts that are "caused" by the business enterprise. Yet some of the rules that have developed to define the scope of employment, particularly in the frolic and detour cases, are difficult to reconcile with a view of the tort law as promoting efficiency.

The economic principles developed here are also useful in the study of vicarious liability outside the employment relationship and outside the common law of torts. Given certain plausible empirical assumptions, many aspects of the law concerning the liability of motor vehicle owners for torts by another driver, the liability of premises owners for torts by intruders, and the liability of employers for sexual harassment by one employee against another may also be understood as an effort to promote efficiency, although other aspects of the law, such as the growing liabilty of landlords for torts by intruders, are harder to justify on economic grounds. 